\title{
Methods for determination of the age of Pleistocene tephra, derived from eruption of Toba, in central India
}

\author{
Rob Westaway ${ }^{1,2, *}$, Sheila Mishra ${ }^{3}$, Sushama DeO ${ }^{3}$ and David R Bridgland ${ }^{4}$ \\ ${ }^{1} M C T$, The Open University, Abbots Hill, Gateshead NE8 3DF, United Kingdom. \\ ${ }^{2}$ NIReS, Newcastle University, Newcastle-upon-Tyne NE1 7RU, United Kingdom. \\ ${ }^{3}$ Department of Archaeology, Deccan College, Pune 411 006, India. \\ ${ }^{4}$ Department of Geography, Durham University, South Road, Durham DH1 3LE, United Kingdom. \\ *e-mail: r.w.c.westaway@open.ac.uk
}

\begin{abstract}
Tephra, emplaced as a result of Pleistocene eruption of the Indonesian 'supervolcano' Toba, occurs at many localities in India. However, the ages of these deposits have hitherto been contentious; some workers have argued that these deposits mark the most recent eruption (eruption A, ca 75 ka), although at some sites they are stratigraphically associated with Acheulian (Lower Palaeolithic) artefacts. Careful examination of the geochemical composition of the tephras, which are composed predominantly of shards of rhyolitic glass, indicates that discrimination between the products of eruption A and eruption D (ca $790 \mathrm{ka}$ ) of Toba is difficult. Nonetheless, this comparison favours eruption D as the source of the tephra deposits at some sites in India, supporting the long-held view that the Lower Palaeolithic of India spans the late Early Pleistocene. In principle, these tephra deposits should be dateable using the $\mathrm{K}$-Ar system; however, previous experience indicates contamination by a small proportion of ancient material, resulting in apparent ages that exceed the true ages of the tephras. We have established the optimum size-fraction in which the material from Toba is concentrated, 53-61 $\mu \mathrm{m}$, and have considered possible origins for the observed contamination. We also demonstrate that Ar-Ar analysis of four out of five of our samples has yielded material with an apparent age similar to that expected for eruption D. These numerical ages, of $809 \pm 51,714 \pm 62,797 \pm 45$ and $827 \pm 39$ ka for the tephras at Morgaon, Bori, Gandhigram and Simbhora, provide a weighted mean age for this eruption of $799 \pm 24$ ka (plus-or-minus two standard deviations). However, these numerical ages are each derived from no more than 10-20\% of the argon release in each sample, which is not ideal. Nonetheless, our results demonstrate that it is feasible, in principle, to date this difficult material using the $\mathrm{Ar}-\mathrm{Ar}$ technique; future follow-up studies will therefore be able to refine our preparation and analysis procedures to better optimize the dating.
\end{abstract}

\section{Introduction}

The Toba caldera, on the Indonesian island of Sumatra (figure 1), is Earth's largest Quaternary 'supervolcano' (e.g., Chesner et al 1991); its eruptions have produced tuffaceous deposits that can be traced across the Indian Ocean and much of south Asia (e.g., Dehn et al 1991; Shane et al 1995; Liu et al 2006). The most recent eruption, ca 75 ka (during Marine Isotope Stage or MIS 4; eruption A of Dehn et al 1991), produced an estimated total volume of ejecta of $\sim 2800 \mathrm{~km}^{3}$, of

Keywords. India; Toba; Pleistocene; tephra; Ar-Ar dating; Lower Palaeolithic. 


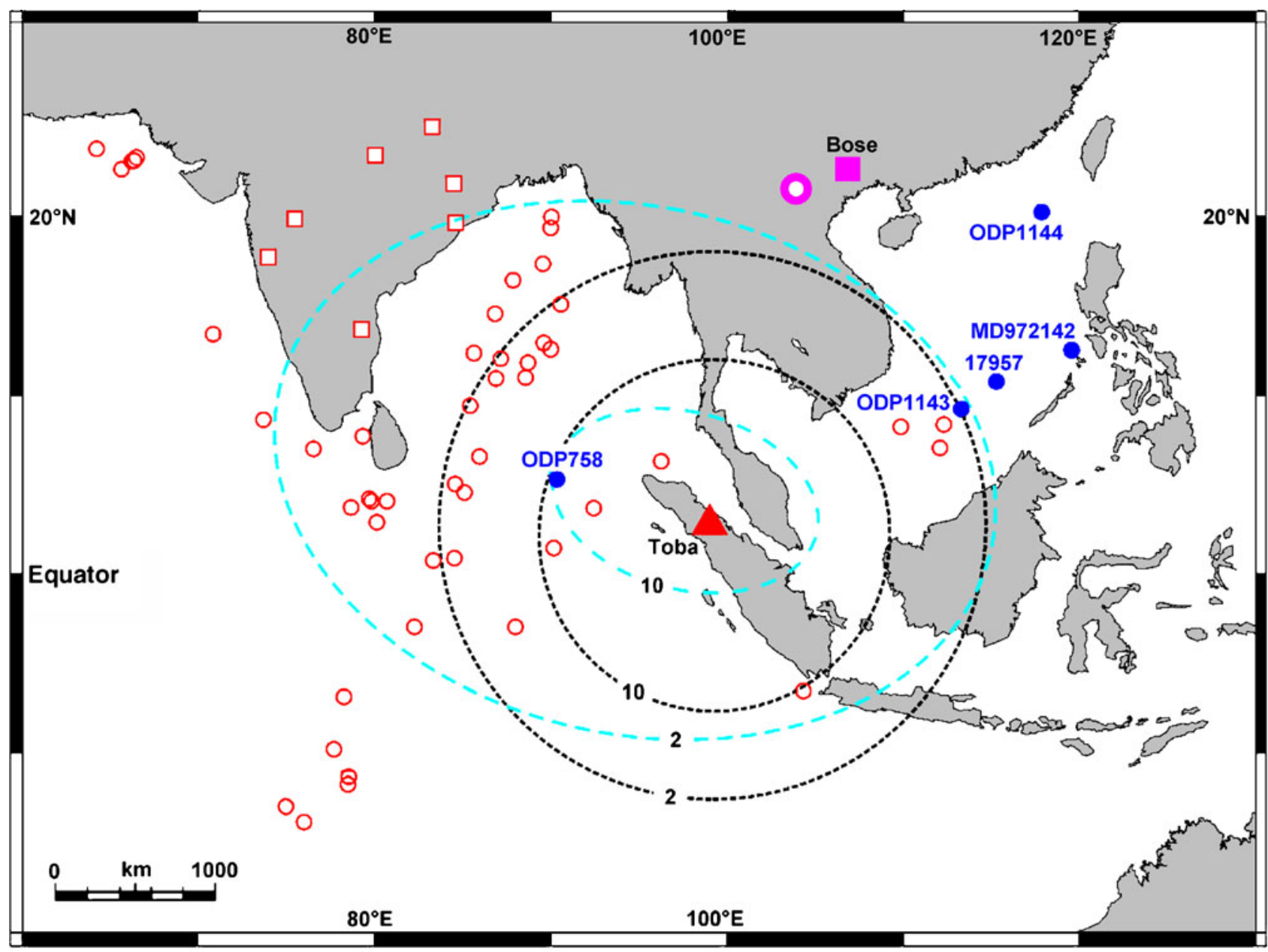

Key:

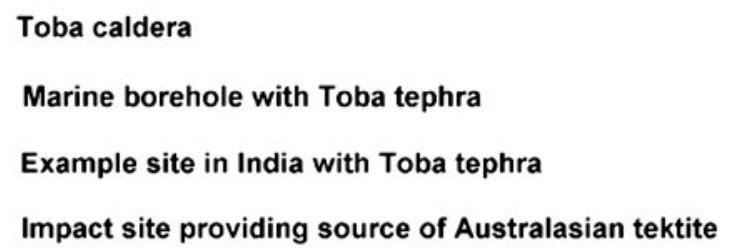

17957 Borehole with geochemical analysis

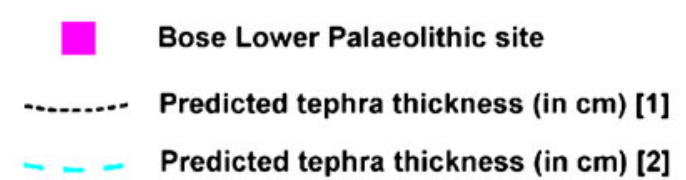

Figure 1. Map of the Indian Ocean and its surroundings, showing locations relevant to this study, modified from figure 1 of Lee et al (2004). The preferred location of the impact crater that produced the Australasian tektites $\left(\sim 22^{\circ} \mathrm{N}, \sim 104^{\circ} \mathrm{E}\right)$ is from Glass and Koeberl (2006), who estimated the crater diameter as $43 \pm 9 \mathrm{~km}$. However, no structure of this size has been identified onshore, suggesting that the impact may have occurred offshore to the southeast, beneath the Gulf of Tonkin or South China Sea. Estimated thicknesses of the Oldest Toba Tephra were calculated by Lee et al (2004) assuming symmetrical dispersal [1] and assuming predominant westnorthwestward dispersal, as for the Youngest Toba Tephra [2]. Glass and Koeberl (2006) envisaged a more extensive fallout pattern for the Oldest Toba Tephra but depicted this as extending roughly west-east from near the western margin of this figure to $\sim 4000 \mathrm{~km}$ east of its eastern margin, although without reaching India. Precise locations of boreholes are listed in table DR1 of Lee et al (2004) and table 1 of Glass and Koeberl (2006).

which $\sim 2000 \mathrm{~km}^{3}$ was emplaced in Indonesia, primarily as pyroclastic flow deposits, and $\sim 800 \mathrm{~km}^{3}$ was dispersed as tephra (e.g., Rose and Chesner 1987, 1990; Jones 2007). The earlier eruption D (Dehn et al 1991), ca $800 \mathrm{ka}$, is now recognised to be of comparable magnitude; Pattan et al (2010) estimated its total volume of ejecta as $\sim 2300 \mathrm{~km}^{3}$. Tephra derived from Toba is widespread in peninsular India, $\sim 3000 \mathrm{~km}$ from its source, having been identified at many Pleistocene sites (figure 2), including some that have yielded Lower Palaeolithic artefacts that have been classified as Large Flake Acheulian (e.g., Sharon 2007; Mishra et al 2009). Previous attempts at dating these tephras in India have yielded a range of numerical ages, including values in excess of $1 \mathrm{Ma}$ (see below). It has also been repeatedly noted in the archaeological literature that the tephras are part of the context of the artefacts, thus dating these tephras constrains the age of the associated 


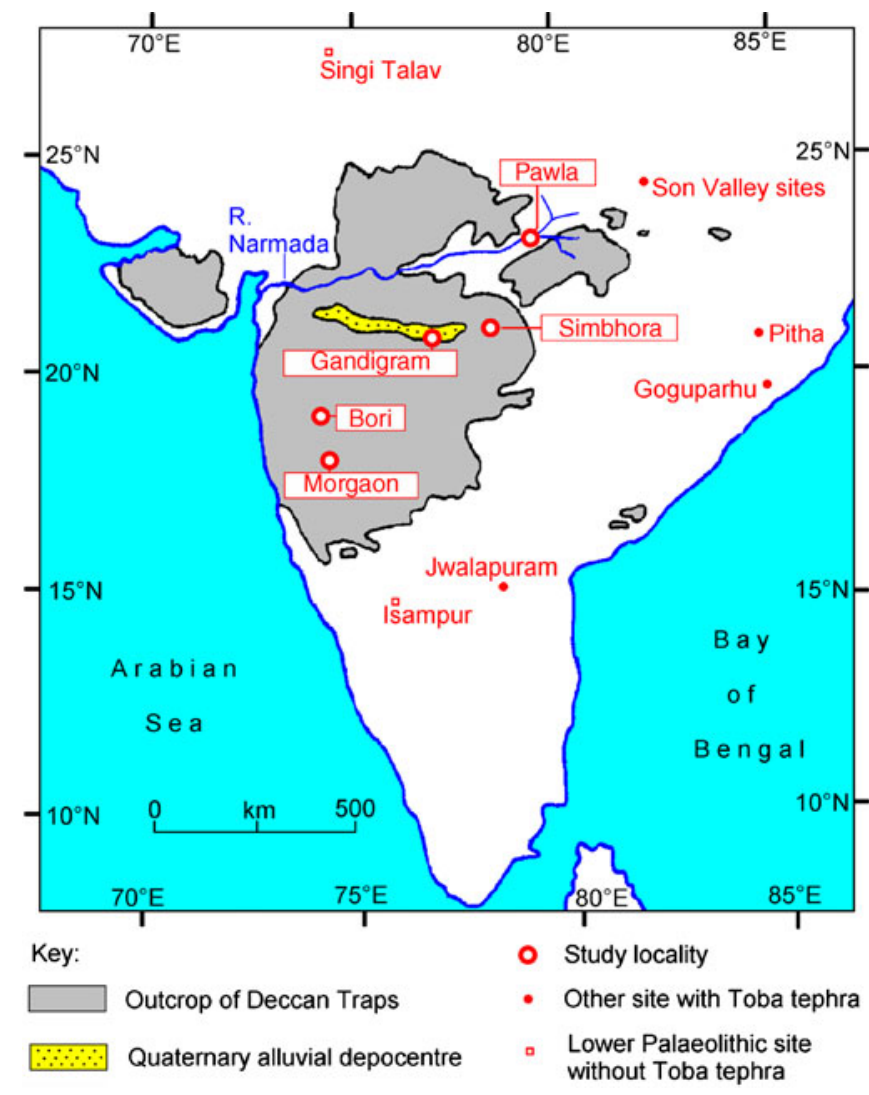

Figure 2. Map of central and southern India, modified from figure 1 of Bose (1972), showing the locations of the Pleistocene sites in India, discussed in this paper, in relation to the outcrop of the Deccan Traps. Maps showing other localities that are mentioned, such as the locations of the Toba caldera and of ODP site 758), are widely available and so are not repeated here (see, e.g., figure 1 of Shane et al 1995). The River Purna flows east-west along the Quaternary alluvial depocentre, depicted around Gandhigram, joining the Tapti and reaching the Arabian Sea coast, a short distance south of the mouth of the Narmada. The River Son flows ENE from headwaters adjoining those of the Narmada, ultimately forming a right-bank tributary of the Ganges. The linear Quaternary depocentre along the course of the River Purna is bounded to the north by a fault (the Gawaligarh Fault), the crustal block to the north of which has been up-thrown, exposing Palaeozoic/Mesozoic sediments beneath the Deccan Traps succession.

archaeology (see below). The contrary view, that the published numerical ages are unreliable and that all the tephra deposits in India date from the most recent eruption of Toba, has also been forcefully argued (e.g., Shane et al 1995; Westgate et al 1998; Petraglia et al 2007).

The aim of this study is to demonstrate that it is possible to date these tephras using the $\mathrm{Ar}-\mathrm{Ar}$ method, although it requires extreme care, including careful preparation of the sample material and sensitive operation of the laser heating equipment (to release argon isotopes from the sample material) during the analysis, to discriminate material derived from Toba from contamination. This paper will summarize the history of previous studies on this topic, before presenting the results of our own analysis of five tephra samples, four of which will be shown to have yielded meaningful numerical ages. However, no attempt will be made to review the Pleistocene stratigraphy of any sites; the existing literature (e.g., Mishra et al 1995; Tiwari et al 1996; Petraglia et al 1999, 2007; Gaffer et al 2001; Westaway et al 2003; Shete 2006; Mishra 2007, 2008; Sangode et al 2007; Gaillard et al 2009; Jones and Pal 2009; and references therein) includes detailed site maps, cross-sections and discussions of stratigraphic relations. The five sites for which tephra samples are analysed are Morgaon, Bori, Gandhigram, Simbhora and Pawla (figure 2). In summary, Acheulian artefacts have been found above the Toba tephra at Bori and below it at Morgaon. At the other three sites, Lower Palaeolithic artefacts have been found in proximity to exposures of tephra, but the stratigraphic relations between the two are unclear; hence, the controversy as to whether the tephras are of comparable antiquity to the artefacts or not.

\section{Previous studies}

Tephra derived from Toba was first reported in the valley of the River Son in north-central India (Madhya Pradesh) by Williams and Royce (1982), and is now known from several adjacent localities in this valley (including Ghogara, Ramnagar, Nakjhar and Khuteli; e.g., Jones and Pal 2009). Toba tephra was first reported in west-central India (Maharashtra) by Korisettar et al (1988), who inferred that it is of considerable antiquity (age $>\sim 400 \mathrm{ka})$ following attempted uranium-series dating. At this time, little was known about the eruption chronology of Toba, other than that the most recent eruption occurred at $\sim 75$ ka (e.g., Ninkovich et al 1978), and that a much older eruption, which produced the Haranggoal dacite tephra, had been dated to $\sim 1.20 \pm 0.16 \mathrm{Ma}( \pm 1 \sigma)$ from fission-track analysis of zircon (Nishimura et al 1977). Onshore in Sumatra, three Toba tephras (all younger than the Haranggoal tephra), known as the 'oldest', 'middle', and 'youngest' Toba tephras, are now distinguished in the field; the 'Youngest Toba Tephra' was emplaced by the $\sim 75$ ka eruption (e.g., Ninkovich et al 1978). Using Ar-Ar dating of sanidine crystals, Diehl et al (1987) subsequently dated the Oldest Toba Tephra to $834 \pm 10 \mathrm{ka}( \pm 1 \sigma)$; using the same method, Chesner et al (1991) dated the Middle Toba Tephra to $501 \pm 5 \mathrm{ka}( \pm 1 \sigma)$.

The eruption chronology of Toba was further clarified as a result of the analysis of borehole records from the Ocean Drilling Program 
(ODP) site 758 (figure 1) in central Indian Ocean (Dehn et al 1991). Dehn et al (1991) designated each eruption alphabetically, working backwards from the Late Pleistocene eruption A. Thus, they identified eruption $\mathrm{C}$ at the transition from MIS 14 to MIS 13, eruption D at the transition from MIS 20 to MIS 19, eruption E during MIS 21, eruption $\mathrm{F}$ at the transition from MIS 46 to MIS 45 and eruption G during MIS 63-61, together with other pre-Pleistocene eruptions (there was no eruption B; tephra formerly thought to mark this was shown by Dehn et al 1991 to be stratigraphically displaced from the rest of the material from eruption A). Dehn et al (1991) also inferred

Table 1. Geochemical discriminants for Toba tephras.

\begin{tabular}{|c|c|c|c|c|c|}
\hline Site & Reference & $n$ & $\begin{array}{c}\mathrm{FeO} \\
(\mathrm{wt} \% ; \pm 2 s)\end{array}$ & $\begin{array}{l}\mathrm{K} / \mathrm{Ca} \\
( \pm 2 s)\end{array}$ & $\begin{array}{c}\mathrm{K}_{2} \mathrm{O} / \mathrm{Na}_{2} \mathrm{O} \\
( \pm 2 s)\end{array}$ \\
\hline \multicolumn{6}{|l|}{ Tephra A } \\
\hline ODP site 758 & 1 & 88 & $0.836 \pm 0.010$ & $7.764 \pm 0.182$ & $1.642 \pm 0.043$ \\
\hline ODP site 758 & 2 & 28 & $0.83 \pm 0.02$ & $7.67 \pm 0.30$ & $1.71 \pm 0.08$ \\
\hline \multirow[t]{2}{*}{ ODP site 758} & 3 & 16 & $0.84 \pm 0.03$ & $7.36 \pm 0.34$ & $1.54 \pm 0.03$ \\
\hline & Mean & 132 & $0.835 \pm 0.009$ & $7.673 \pm 0.141$ & $1.585 \pm 0.024$ \\
\hline \multicolumn{6}{|l|}{ Tephra C } \\
\hline ODP site 758 & 1 & 20 & $0.985 \pm 0.013$ & $8.392 \pm 0.552$ & $1.543 \pm 0.049$ \\
\hline ODP site 758 & 2 & 12 & $1.00 \pm 0.01$ & $9.35 \pm 0.94$ & $1.50 \pm 0.07$ \\
\hline \multirow[t]{2}{*}{ ODP site 758} & 3 & 18 & $1.02 \pm 0.03$ & $8.95 \pm 0.63$ & $1.33 \pm 0.05$ \\
\hline & Mean & 50 & $0.996 \pm 0.008$ & $8.751 \pm 0.380$ & $1.451 \pm 0.031$ \\
\hline \multicolumn{6}{|l|}{ Tephra D } \\
\hline ODP site 758 & 1 & 19 & $0.832 \pm 0.015$ & $7.762 \pm 0.273$ & $1.784 \pm 0.354$ \\
\hline Borehole 17957 & 4 & 26 & $0.85 \pm 0.03$ & $8.191 \pm 0.236$ & $1.73 \pm 0.06$ \\
\hline Borehole MD972142 & 4 & 14 & $0.87 \pm 0.03$ & $8.720 \pm 0.317$ & $1.69 \pm 0.06$ \\
\hline ODP site 1143 , layer 2 & 4 & 10 & $0.86 \pm 0.07$ & $8.475 \pm 0.488$ & $1.64 \pm 0.04$ \\
\hline \multirow[t]{2}{*}{ ODP site 1143 , layer B } & 5 & 10 & $0.90 \pm 0.06$ & $6.920 \pm 0.534$ & $1.525 \pm 0.129$ \\
\hline & Mean & 79 & $0.843 \pm 0.012$ & $8.114 \pm 0.143$ & $1.668 \pm 0.027$ \\
\hline \multicolumn{6}{|l|}{ Tephra E } \\
\hline ODP site 758 & 1 & 19 & $1.226 \pm 0.023$ & $5.517 \pm 0.132$ & $1.081 \pm 0.031$ \\
\hline ODP site 758 & 2 & 11 & $1.21 \pm 0.02$ & $5.47 \pm 0.20$ & $1.07 \pm 0.05$ \\
\hline \multirow[t]{2}{*}{ ODP site 758} & 3 & 20 & $1.23 \pm 0.03$ & $5.58 \pm 0.21$ & $1.02 \pm 0.02$ \\
\hline & Mean & 50 & $1.220 \pm 0.013$ & $5.519 \pm 0.098$ & $1.041 \pm 0.016$ \\
\hline \multicolumn{6}{|l|}{ Tephra F } \\
\hline ODP site 758 & 1 & 9 & $1.145 \pm 0.063$ & $6.698 \pm 0.620$ & $1.609 \pm 0.067$ \\
\hline
\end{tabular}

Reference sources for here and table 3 are: 1, Dehn et al (1991); 2, Shane et al (1995); 3, Westgate et al (1998); 4, Lee et al (2004); 5, Liang et al (2001); and 6, Petraglia et al (2007). Column $n$ indicates the number of glass shards analysed in each study; FeO is the mean percentage by weight of iron in each sample, expressed as normative iron II oxide; $\mathrm{K} / \mathrm{Ca}$ is the mean ratio of numbers of atoms of potassium and calcium, obtained from data on normative percentages by weight of oxides by multiplying by $112 / 94 ; \mathrm{K}_{2} \mathrm{O} / \mathrm{Na}_{2} \mathrm{O}$ is the mean ratio of percentages by weight of normative oxides of potassium and sodium; all margins of uncertainty are expressed as twice the standard error in each mean value.

Data from reference 1, table 2 of Dehn et al (1991), have been recalculated to $100 \%$ on a volatile-free basis (for comparability with the other datasets), then analysed, using the standard method, to determine mean values and their standard errors. K/Ca ratios have been calculated from ratios of listed percentages by weight of $\mathrm{K}_{2} \mathrm{O}$ and CaO, after multiplication by $112 / 94$ or $\sim 1.19$ to correct for atomic abundances and relative formula masses. For tephra C, the 20 analyses of glass shards include five with very high $\mathrm{K} / \mathrm{Ca}$ ratios, above 10; such high ratios may result from uptake of potassium as a result of low-temperature hydrothermal alteration within the ocean, and may thus not be representative of the composition of the material as erupted (Dehn et al 1991). The table lists the mean $\mathrm{K} / \mathrm{Ca}$ and $\mathrm{K}_{2} \mathrm{O} / \mathrm{Na}_{2} \mathrm{O}$ ratios after these five data are excluded; their inclusion would change these ratios to $9.057 \pm 0.674$ and $1.499 \pm 0.063$ (both $\pm 2 s$ ). The data for tephra $\mathrm{D}$ include six analyses of glass shards from tephra d, as identified in ODP borehole 758B; Dehn et al (1991) concluded that tephras D and d mark the same eruption of Toba. The error bounds listed for FeO are much tighter than those determined for the same dataset by Shane et al (1995); this is partly because they reported sample standard deviations, not standard errors in the mean, and partly because they did not include all the available data from Dehn et al (1991), even though their text indicates otherwise.

Reference sources 2, 3 and 5 are table 1 of Shane et al (1995), table 2 of Westgate et al (1998), and table DR2 of Lee et al (2004). In each of these sources only site mean data, not data from individual glass shards have been reported, so the data have been analysed (after conversion of the measure of uncertainty to the standard error in the mean, and conversion to atomic abundances rather than percentages of oxides by weight) assuming that the variations in $\mathrm{K}$ and Ca abundances between the individual glass shards (and percentages by weight of $\mathrm{K}_{2} \mathrm{O}$ and $\mathrm{Na}_{2} \mathrm{O}$ ) are uncorrelated. Details of the equipment used for the analyses are provided in the cited references and so are not repeated here. 
from the thicknesses of tuffaceous material on the Indian Ocean floor that the largest Pleistocene eruptions were those designated G, D, C and $\mathrm{A}$; these are thus the eruptions most likely to have produced recognisable tephra deposits as far away as India. Chesner et al (1991) and others established that tephra A was emplaced by the eruption that produced the Youngest Toba Tephra. Dehn et al (1991) associated the Middle Toba Tephra with eruption C (cf. Chesner et al 1991), and tentatively interpreted the source of the Oldest Toba Tephra as eruption E, although noting an apparent mismatch between the latter age assignment, based on the Ar-Ar dating by Diehl et al (1987), and the results of their cyclostratigraphic analysis (which placed the MIS 20-19 transition at $\sim 730 \mathrm{ka}$ and MIS 21 at $\sim 775 \mathrm{ka}$ ). However, the recalibration of the MIS timescale around the Early-Middle Pleistocene boundary by Shackleton et al (1990) adjusted these two points to $\sim 780$ and $\sim 850 \mathrm{ka}$. The same recalibration would adjust the cyclostratigraphic age of eruption $\mathrm{D}$ to $\sim 800 \mathrm{ka}$, somewhat below the numerical age of the Oldest Toba Tephra from Diehl et al (1987) and would also adjust the revised cyclostratigraphic age of eruption E to $\sim 850$ ka (MIS 21), somewhat above this numerical age. It is thus unclear from this information whether eruption D or eruption E produced the latter tephra; however, given that the younger of these eruptions was larger (Dehn et al 1991), it is arguably the stronger candidate. Izett and Obradovich (1994) subsequently reported a sanidine Ar-Ar date of $789 \pm 12 \mathrm{ka}( \pm 2 \sigma)$ for the Oldest Toba Tephra, whereas Hall and Farrell (1995) obtained a biotite Ar-Ar date of $799.7 \pm$ $19.9 \mathrm{ka}( \pm 2 \sigma)$ for eruption $\mathrm{D}$, using material from ODP site 758 . This tentative association between the Oldest Toba Tephra and eruption D has since been confirmed by Lee et al (2004) and Chen et al (2004) (see below). Furthermore, Petraglia et al (2007) provided geochemical analyses of rhyolitic glass shards from the source area that indicate much greater geochemical similarity with the tephra of eruption D on the Indian Ocean floor than with that from eruption $\mathrm{E}$ (for example, these glass shards have a typical $\mathrm{K}_{2} \mathrm{O} / \mathrm{Na}_{2} \mathrm{O}$ ratio of $2.78 \pm 0.41, \pm 2 s$, or twice the standard error in the mean: cf. table 1). Pattan et al (2010) have subsequently confirmed these conclusions.

Regarding the onshore exposures in India, Korisettar et al (1989) reported a whole-rock K-Ar date for Toba tephra from Bori, in Maharashtra, of $1380 \pm 240$ ka. Horn et al (1993) used magnetic separation to remove magnetic minerals from the Bori tephra, obtaining a $\mathrm{K}-\mathrm{Ar}$ date on the resulting non-magnetic fraction of $538 \pm 47 \mathrm{ka}( \pm 1 \sigma)$; they also reported a fission-track date from the same glass sample of $640 \pm 290 \mathrm{ka}( \pm 1 \sigma)$, as well as a thermoluminescence (TL) date of $23.4 \pm$ 2.4 ka. Mishra et al (1995) reported three Ar-Ar dates for the Bori tephra, as listed in table 2. To obtain these they used sieving to remove material with particle size $<43 \mu \mathrm{m}$ and also used a magnetic separator to remove magnetic materials, primarily biotite, thus restricting the dating to the glassy component of the tephra. For each of the samples, $\sim 60-80 \%$ of the ${ }^{39} \mathrm{Ar}$ release occurred in step-heating splits with Middle Pleistocene apparent ages, the highest-temperature argon release splits being associated with much older apparent ages. Mishra et al (1995) concluded that their sample $1 \mathrm{~B}$, which yielded the weighted plateau age of $540 \pm 30$ ka $( \pm 1 \sigma)$, was disturbed and, thus, averaged together the ages of their other two samples (1A and 3$)$ to obtain a best estimate of the age for the site of $670 \pm 30 \mathrm{ka}( \pm 1 \sigma)$. Mishra et al (1995) also reported $\mathrm{Ar}-\mathrm{Ar}$ dates of $15.5 \pm 1.3 \mathrm{Ma}$ $( \pm 1 \sigma)$ and $16.3 \pm 1.3 \mathrm{Ma}( \pm 1 \sigma)$ for the magnetic minerals separated out from their samples $1 \mathrm{~B}$ and 3 ; however, they offered no explanation for these numerical ages or for the apparent ages of the material contibuting the highest-temperature argon release splits for their glass samples. It is nonetheless apparent from this preliminary study that the analysed samples consisted of a mixture of materials derived from Toba and a small proportion of more ancient material. The whole-rock date by Korisettar et al (1989) was evidently, likewise, for a mixture of Pleistocene material with a small proportion of ancient material, and therefore overestimated the age of the site. We later discuss possible sources of this ancient contamination of the sample material.

Acharyya and Basu (1993) proposed that all the tephra deposits in India are derived from the $\sim 75$ ka eruption of Toba, thus providing a unique marker horizon for stratigraphic correlation across India. They also commented that the reported 1.4-myr $\mathrm{K}-\mathrm{Ar}$ age of [the Bori] ash sample... is very old and unrealistic'. Mishra and Rajaguru (1994) noted, in response, that such a young age assignment is incompatible with the Lower Palaeolithic artefacts associated with the Bori tephra,

Table 2. Previous Ar-Ar dating results.

\begin{tabular}{lcc}
\hline Sample & $\begin{array}{c}\text { Total fusion } \\
\text { Age }(\mathrm{ka} ; \pm 1 \sigma)\end{array}$ & $\begin{array}{c}\text { Weighted plateau } \\
\text { Age }(\mathrm{ka} ; \pm 2 \sigma)\end{array}$ \\
\hline $1 \mathrm{~A}$ & $1810 \pm 30$ & $680 \pm 30$ \\
$1 \mathrm{~B}$ & $1040 \pm 30$ & $540 \pm 30$ \\
3 & $1500 \pm 20$ & $660 \pm 10$ \\
\hline
\end{tabular}

This table summarises the Ar-Ar dating results of Mishra et al (1995) for three samples of the tephra from Bori. 
that different eruptions of Toba produced tephras which are chemically rather similar, and that tephras of different ages may thus be present in different parts of India. Shane et al (1995) presented geochemical analyses which, they argued, enable all the studied tephras in India to be uniquely correlated with the youngest Toba eruption. Regarding the Bori site, they thus claimed that there is a distinction between in situ Lower Palaeolithic artefacts, which are much older than the tephra that is present, and artefacts in sediments associated with this tephra deposit, which they regarded as reworked. Mishra and Rajaguru (1996) argued that Shane et al (1995) had not correctly described the stratigraphy at Bori, which was known in detail, and that it is implausible that any of the Lower Palaeolithic artefacts found at this site have been reworked, as they are made of basalt, a material that would not survive prolonged or repeated transport.

The final riposte in this 1990s exchange of ideas was by Westgate et al (1998), who reported additional geochemical analyses of glass shards from Toba tephras from more sites in India, which in their view established once and for all that all these tephras date from the most recent eruption. Westgate et al (1998) also presented two new fission-track dates, on tephra samples from Pawlaghat (or Pawla) in the Narmada valley (Madhya Pradesh) and Gandhigram in the Purna valley (Maharashtra), respectively $121 \pm 22$ and $84 \pm 16$ ka. Regarding the chronology and stratigraphy at Bori, they asserted that none of the $\mathrm{K}$-Ar or $\mathrm{Ar}-\mathrm{Ar}$ dates published previously were reliable, because they could have been derived from mixtures of glass shards of different ages with similar properties, although there was no suggestion regarding the provenance of this hypothetical older rhyolitic glass. Westgate et al (1998) also noted that the $670 \pm 30 \mathrm{ka}( \pm 1 \sigma)$ age estimate for the Bori site, from Mishra et al (1995), does not relate to any known eruption of Toba, indicating that this numerical age must be wrong. Westgate et al (1998) thus asserted that, apart from their own fission track dates, the only age control then available from any Indian tephra site was the $23.4 \pm 2.4 \mathrm{ka}$ TL date by Horn et al (1993), which in their view marked the most recent reworking of the sediments at Bori.

Subsequent investigations have led to the conclusion that other Lower Palaeolithic sites in India, associated with deposits of Toba tephra, also date from the Early Pleistocene or early Middle Pleistocene, on the basis of stratigraphic relations, magnetostratigraphy, and limited evidence from numerical dating. The current state of knowledge on this topic was reviewed by Gaillard et al (2009), notwithstanding Chauhan's (2010) com- ment that the story is 'based entirely on circumstantial and inconclusive evidence' (cf. Gaillard et al 2010); Gaillard et al (2009) concluded that there is a strong weight of evidence, from the presence of Acheulian artefacts, for human occupation of the region in the late Early Pleistocene. For example, Sangode et al (2007) have reported reversed magnetization in sediments associated with Acheulian artefacts and the tephra at Morgaon, Maharashtra, and at Bori, implying ages within the Matuyama chron (i.e., within the Early Pleistocene). Furthermore, sediments at the Amarpura site near Didwana in Rajasthan have been dated using the electron spin resonance (ESR) technique to $797 \mathrm{ka}$ (with no stated error margin) by Kailath et al (2000); Acheulian artefacts have been reported from the Amarpura section (Misra et al 1982) and also in what appear to be stratigraphically equivalent sediments $\sim 4 \mathrm{~km}$ away, at Singi Talav (Gaillard et al 2009). In addition, at Isampur in Karnataka, ESR dating of bovid tooth enamel, associated with a quarry where artefacts were produced (e.g., Petraglia et al 1999), yielded a probable age of $1270 \pm 170 \mathrm{ka}$ and a minimum age of $730 \pm 100 \mathrm{ka}$, subject to different assumptions about the history of uptake of radioactive elements by the sample material (Paddayya et al 2002).

Others, however, have reached different conclusions. For example, Petraglia et al (2007) presented a study of Middle Palaeolithic artefacts from Jwalapuram near the city of Kurnool (in Andhra Pradesh, southeastern India), in the valley of the River Jurreru, which flows eastward into the Bay of Bengal. This study was supported by optically-stimulated luminescence (OSL) dating and by geochemical analysis of interbedded Toba tephra. Petraglia et al (2007) concluded that the Toba eruption represented in this locality is the $\sim 75$ ka eruption A, thereby asserting once again on the basis of geochemical similarity that the same eruption also produced all the occurrences of Toba tephra in India. Jones and Pal (2009) have reviewed the state of knowledge regarding the Quaternary succession in the Son Valley, the locality where Toba tephra was first reported in India (Williams and Royce 1982). Jones and Pal (2009) discussed the merits of different stratigraphic correlation schemes proposed for this locality by previous authors, which are not mutually consistent, and noted that the tephra found locally has been assigned to the $\sim 75$ ka eruption (e.g., Westgate et al 1998), but also that Acheulian artefacts have been found in sediments both stratigraphically below and above this tephra layer. They noted that one would not expect use of Lower Palaeolithic artefacts in the Late Pleistocene, but also that the artefact finds have not been made precisely in localities where stratigraphic relations between 
the sediments and tephra are established; they concluded that the $\sim 75 \mathrm{ka}$ tephra is indeed present, but that the geology has been incorrectly correlated between the sites.

In the meantime, Hou et al (2000) have reported 'Acheulian-like' artefacts in sediments of the Bose Basin of southern China (figure 1). These artefacts occur at the stratigraphic level of the 'Australasian' tektite deposit, thought to originate from the impact in southeast Asia (probably in the China-Vietnam-Laos-Thailand border region; figure 1) of an asteroid or comet (e.g., Schneider et al 1992; Pillans 2004; Glass and Koeberl 2006); Hou et al (2000) obtained an Ar-Ar isochron age of $803 \pm 3 \mathrm{ka}( \pm 1 \sigma)$ and an Ar-Ar weighted plateau age of $802 \pm 3 \mathrm{ka}( \pm 1 \sigma)$ for this tektite material. This tektite is also found in borehole records from the South China Sea (e.g., at ODP site 1144; figure 1), where it can be dated to $804 \pm 4$ ka from the oxygen isotope stratigraphy (Lee et al 2004), assuming the Bassinot et al (1994) age model (with the Matuyama-Brunhes transition at $778 \mathrm{ka}$ ) and also assuming a constant sedimentation rate across the intervening interval of time.

A final issue concerns the disposition of Toba tephras and associated sediments, which are invariably found within river valleys, close to modern river levels (many authors have noted that corresponding deposits are not found in interfluves). Much of peninsular India is formed in cratonic Archaean crust; by analogy with other regions one does not expect significant vertical crustal motions, such that sediments of a wide range of ages may be found close to modern river levels (Westaway et al 2003, 2009; Bridgland and Westaway 2007). In contrast, in younger continental crust, such as that which typifies Europe, uplift predominates in continental interior regions, such that only the youngest fluvial terrace deposits occur close to modern river levels (Bridgland and Westaway 2007; Westaway et al 2009). However, as well as the Archaean cratonic nuclei, peninsular India also consists of a mosaic of younger mobile belts that mark the suturing together of the continent during the Proterozoic (e.g., Sharma 2009). Proterozoic continental crust has a composition different from cratonic Archaean crust; notably, it typically contains a thick mafic layer at its base (e.g., Durrheim and Mooney 1994). As a result, it can sustain quite complex patterns of uplift and subsidence, although the typically limited net vertical crustal motions on long timescales often cause long gaps in sedimentary records (Bridgland and Westaway 2007; Westaway et al 2009). One thus expects quite complex variations in vertical crustal motions (both spatially and over time) across peninsular India, consistent with the observation that some rivers have developed long-timescale fluvial terrace staircases whereas others have not (e.g., Korisettar and Rajaguru 1998; Bridgland and Westaway 2007). As Korisettar and Rajaguru (1998) pointed out, for many decades Quaternary research in India assumed that sedimentary successions match those expected in Europe, with deposits present from each climate cycle, and with the same sequence of deposits expected in widely-separated localities. In many legacy chronologies, established on this basis, the end of the Lower Palaeolithic in India was placed in the Late Pleistocene (Korisettar and Rajaguru 1998); one even finds this stated in some modern publications (e.g., Paddayya 2007 placed this event at $70 \mathrm{ka}$ ). Similar problems have affected the development of Quaternary chronologies in other regions; for example, a legacy chronology for the deposits of the River Euphrates in the northern Arabian Platform, another region of Proterozoic crust, was recently superseded by a chronology based on isotopic dating, in which the succession has been shown to extend much further back in time than previously thought, with no sediments preserved from most of the Middle Pleistocene climate cycles (e.g., Demir et al 2007, 2008). It is thus apparent, a priori, that there is no particular reason why the deposits of Toba tephra found in India, close to modern river levels, are all from Late Pleistocene or, indeed, should all be from the same eruption of Toba. For comparison, tephra deposits from multiple Pleistocene 'super-eruptions' of the Yellowstone and Valles Caldera volcanic centres are widespread across North America.

\section{Synthesis of available evidence}

The key conclusions of the Westgate et al (1998) analysis (discussed above) can be summarized as follows. First, the individual eruptions of Toba produced chemically distinct tephras, which can be distinguished from one another using geochemical criteria, such as the ratio of contents of calcium, potassium and sodium. As a result, it can be stated with confidence that all exposures of tephra in India are derived from the most recent eruption of Toba. Second, dating of Pleistocene tephras in India using the $\mathrm{K}-\mathrm{Ar}$ or $\mathrm{Ar}-\mathrm{Ar}$ method is impossible because the Pleistocene material derived from Toba is mixed with much older material of unknown provenance, which is compositionally indistinguishable. The only reliable dating evidence, demonstrating Late Pleistocene ages of tephra deposits, comes from the TL date by Horn et al (1993) and the two fission-track dates by Westgate et al (1998). It is important to consider these points carefully. 


\subsection{Compositional variations}

Regarding chemical composition, figure 3 shows a plot of the $\mathrm{K}_{2} \mathrm{O} / \mathrm{CaO}$ ratio against the $\mathrm{K}_{2} \mathrm{O} / \mathrm{Na}_{2} \mathrm{O}$ ratio for the tephra samples from ODP site 758 that were analysed by Dehn et al (1991). Each of the tephras can be seen to have considerable compositional variability, as Dehn et al (1991) noted. Between four of the five tephras plotted (A, C, D and $\mathrm{F}$ ), there is no apparent pattern of variability; however, tephra $\mathrm{E}$ is clearly characterized by lower ratios of $\mathrm{K}_{2} \mathrm{O} / \mathrm{CaO}$ and $\mathrm{K}_{2} \mathrm{O} / \mathrm{Na}_{2} \mathrm{O}$. Westgate et al (1998) recognized the compositional difference of tephra $\mathrm{E}$, on the basis of ratios of these elements, but also argued that tephras $\mathrm{A}$ and $\mathrm{C}$ can be distinguished using the same method; they claimed that tephra $\mathrm{C}$ is characterized by higher $\mathrm{K}_{2} \mathrm{O} / \mathrm{CaO}$ ratios and lower $\mathrm{K}_{2} \mathrm{O} / \mathrm{Na}_{2} \mathrm{O}$ ratios than tephra A. There are two principal differences between the Westgate et al (1998) and Dehn et al (1991) datasets: the former was analysed using more modern equipment and included fewer samples than the latter. Regarding the analytical technologies used, Shane et al (1995) reported that they had no discernable effect on the results; it is thus surprising that Westgate et al (1998) should later resolve a geochemical variation that was not apparent in the original dataset. The second factor thus appears critical; the substantial compositional variability of each tephra means that the analysis of a small number of samples can reveal apparent variations that might disappear if a larger dataset were to be studied.

An additional criterion for use in discrimination between the different tephras, used by both Dehn et al (1991) and Shane et al (1995), was the concentration of iron (quantified as the percentage by

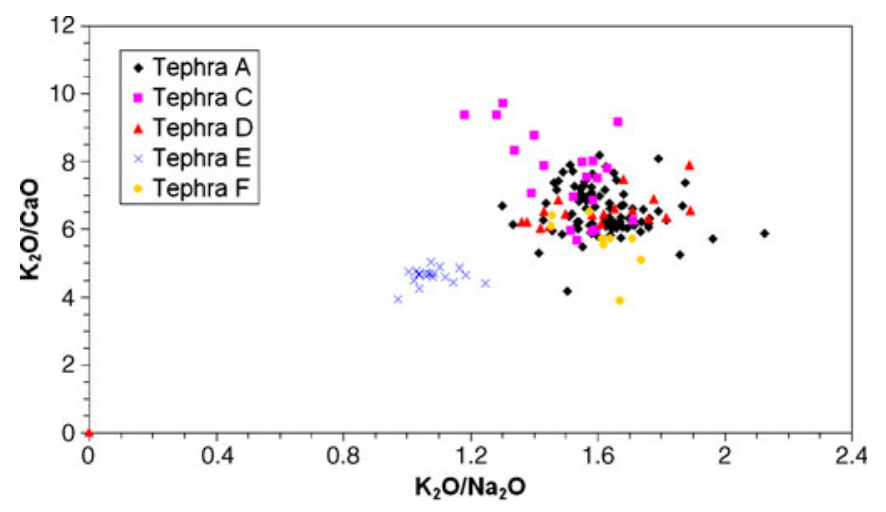

Figure 3. Major element discrimination diagram for Toba tephras A, C, D, E and F, using measurements of percentages by weight of normative $\mathrm{CaO}, \mathrm{K}_{2} \mathrm{O}$ and $\mathrm{Na}_{2} \mathrm{O}$ from Dehn et al (1991); each data point is for the analysis of a single rhyolitic glass shard from ODP site 758 . Note the variability of the compositions and the resulting overlaps in the measurements for different tephras, except for tephra E that is clearly distinguishable from the others. weight of normative iron oxide, expressed as $\mathrm{FeO}$ ). Shane et al (1995) illustrated these variations graphically, in a manner that appeared to demonstrate that glass shards from tephras A, C and E contain systematically greater concentrations of $\mathrm{FeO}$. Furthermore, their analyses of individual glass shards from Indian tephras also appeared to indicate compositional variability, with individual measurements overlapping the $\mathrm{FeO}$ concentrations expected for tephras A and C. However, neither Shane et al (1995) nor Westgate et al (1998) (nor, indeed, Petraglia et al 2007) reported their datasets completely; they merely tabulated the mean concentrations of all glass shards in each sample, not the measurements from the individual shards.

The principal conclusion, regarding composition, that can be drawn from the analyses by Shane et al (1995) and Westgate et al (1998) is that no Indian tephra sample has the same composition as tephra E. However, in neither study was any comparison with tephra D undertaken, which seems more likely (on the basis of volume of material erupted and the existing information regarding the dating and geochemistry; see above) to have reached India in significant quantity. Liang et al (2001), Chen et al (2004) and Lee et al (2004) have subsequently argued on the basis of major element geochemistry and ${ }^{87} \mathrm{Sr} /{ }^{86} \mathrm{Sr}$ data that the Oldest Toba Tephra correlates with tephra D on the Indian Ocean floor; Lee et al (2004) also reported an age of $788.0 \pm 2.2 \mathrm{ka}$ for tephra $\mathrm{D}$ by correlation with the Bassinot et al (1994) oxygen isotope chronology. Shane et al (2004) disputed these conclusions on several grounds, including the mismatch with the Diehl et al (1987) date, although the numerical age obtained by Chen et al (2004) is concordant with the Izett and Obradovich (1994) and Hall and Farrell (1995) dates. Given the volume of ejecta of at least $800-1000 \mathrm{~km}^{3}$ that they estimated for the eruption that produced the Oldest Toba Tephra, Lee et al (2004) envisaged that with predominant westward dispersal (such as for the Youngest Toba Tephra) this material could have readily reached India in sufficient quantity to enable preservation within the geological record (figure 1). The possibility of such preservation is increased by the upward revision of the magnitude of this eruption, to $\sim 2300 \mathrm{~km}^{3}$, by Pattan et al (2010).

To ascertain whether there are any significant differences in the compositional criteria, used in earlier literature, between tephras A, C and D, we have compiled analytical results from the ODP site 758 and other boreholes (see figure 1 for locations), and have used the data to calculate overall mean values for each tephra (table 1). We thus confirm the conclusion of Westgate et al (1998) that tephra $\mathrm{C}$ typically has lower $\mathrm{K}_{2} \mathrm{O} / \mathrm{Na}_{2} \mathrm{O}$, 
higher $\mathrm{K}_{2} \mathrm{O} / \mathrm{CaO}$, and higher $\mathrm{FeO}$ than tephra A. However, as table 1 indicates, distinction between tephras A and D using these geochemical criteria is much less straightforward. It is apparent that these two tephras have similar compositions; thus, the argument by Westgate et al (1998) that on compositional grounds all samples from India are of tephra A might equally well indicate that at least some of them are tephra D, a possibility that Westgate et al (1998) did not consider. Nonetheless, when all the data listed in table 1 are grouped, they indicate that the $\mathrm{K} / \mathrm{Ca}$ and $\mathrm{K}_{2} \mathrm{O} / \mathrm{Na}_{2} \mathrm{O}$ ratios for tephras $\mathrm{A}$ and $\mathrm{D}$ differ at the level of plus or minus two times the standard error in the mean. Although the mean $\mathrm{FeO}$ contents listed in table 1 do not differ significantly, it is apparent that this parameter has greater variability in tephra D than in tephra A. In particular, although the overall mean $\mathrm{FeO}$ content for tephra D is estimated as $0.84 \pm 0.01 \mathrm{wt} \%$, the same as for tephra A, it is apparent that some samples of tephra D (including those from the South China Sea, analysed by Liang et al 2001) have $\mathrm{FeO}$ content of $0.9 \mathrm{wt} \%$ or higher. Using the criterion of a mean $\mathrm{FeO}$ content of $>0.9$ wt\% to discriminate tephra $\mathrm{D}$ from tephra A, the data in table 3 indicate that the Kukdi and Son valleys represent tephra D, consistent with the reported associations of these tephras with Lower Palaeolithic artefacts (e.g., Mishra et al 1995; Jones and Pal 2009). Of the other sites listed, Kurnool/Jwalapuram clearly represents tephra A (Petraglia et al 2007); for the others, one cannot say on the basis of geochemical composition whether they represent tephra A or tephra D.

\subsection{Luminescence and fission-track dating}

The conclusion of Westgate et al (1998) that the tephra at Bori can clearly be correlated with the most recent eruption of Toba on the basis of TL and fission-track dating also warrants scrutiny. In TL dating (and in other variants of luminescence dating, such as OSL) it is essential to control for the possibility of systematic errors that may make a numerical age underestimate (or overestimate) the true age of a sample. True ages will be underestimated if a sample has experienced an uptake of radioactive elements since deposition, as this will mean that the measured present-day radiation dose rate exceeds the typical dose rate to which, over time, the sample has been exposed (e.g., Li et al 2007, 2008). Moreover, there have been instances where luminescence dating has produced numerical ages that are much younger than the true ages of sediments, because samples for which the response to the radiation dose has become saturated have been mistaken for material in which this response is proportional to the applied dose and thus indicative of the sample age. An example of this problem is provided by OSL dating of the terrace staircase of the River Loire in western France (Straffin et al 1999; Blum and Straffin 2001; Colls et al 2001) which reached the conclusion that a fluvial sequence spanning time since the Early Pleistocene has been emplaced during the last climate cycle (Westaway 2004); in other words, OSL produced Late Pleistocene numerical ages for Middle Pleistocene deposits.

In principle, the fission-track ages are also problematic; it is well known that fission-tracks in volcanic glass are prone to spontaneous annealing or 'fading' under ambient temperature conditions, and that this effect has resulted in many instances where this technique has produced numerical ages that dramatically underestimate the true ages of samples (e.g., Naeser et al 1980; Naeser and Naeser 1984; Bigazzi et al 1993, 2004; Walker 2005, p. 116). Annealing of fission tracks is thus expected to be of particular concern in any region with a hot climate; for example, daytime temperatures as high as $43^{\circ} \mathrm{C}$ have been recorded in Pune (Maharashtra), and similar temperatures can be anticipated during Pleistocene interglacials. Westgate et al (1998) asserted that tests that they carried out indicate that fission-track annealing in their samples has been minimal (and indeed, the small magnitude of the resulting correction provides confirmation that the samples must be very young), but provided no supporting documentation. A further difficulty is that the fission-track ages obtained, $121 \pm 22$ and $84 \pm 16 \mathrm{ka}$, exceed the age of Toba eruption A. Westgate et al (1998) averaged these two dates together with a third, for a sample from Malaysia that is unequivocally from eruption A, to obtain a mean age of $79 \pm$ 8 ka. However, it is by no means clear that this averaging is valid; for example, on compositional grounds (see above) the tephra deposits from which the fission-track dating samples were derived (samples UT1069 and UT1070; table 3) might represent either tephra A or tephra D.

Owing to the above issues, we attempt, once again, to determine, using the $\mathrm{K}-\mathrm{Ar}$ and $\mathrm{Ar}-\mathrm{Ar}$ techniques, the ages of tephra deposits in India, for which late Early Pleistocene and early Middle Pleistocene ages have previously been inferred.

\section{Analysis procedure}

Samples of tephra were collected in the field from five sites adjoining rivers in peninsular India; from southwest to northeast, these were Morgaon, Bori, Gandhigram, Simbhora and Pawla (figure 2), yielding samples MRG, BRI, GND, WRD, and PWL, respectively. Morgaon, southeast of Pune, adjoins 
Table 3. Geochemical discriminants for Toba tephras in India.

\begin{tabular}{|c|c|c|c|c|c|}
\hline Locality/Tephra & Ref. & $n$ & $\begin{array}{c}\mathrm{FeO} \\
(\mathrm{wt} \% ; \pm 2 s)\end{array}$ & $\begin{array}{l}\mathrm{K} / \mathrm{Ca} \\
( \pm 2 s)\end{array}$ & $\begin{array}{c}\mathrm{K}_{2} \mathrm{O} / \mathrm{Na}_{2} \mathrm{O} \\
( \pm 2 s)\end{array}$ \\
\hline \multicolumn{6}{|l|}{ Kukdi valley } \\
\hline UT1068; Kukdi valley & 2 & 10 & $0.89 \pm 0.04$ & $7.90 \pm 0.67$ & $1.50 \pm 0.05$ \\
\hline UT1068; Bori, Kukdi River & 3 & 20 & $0.90 \pm 0.03$ & $7.54 \pm 0.39$ & $1.58 \pm 0.03$ \\
\hline \multirow[t]{2}{*}{ UT1072; Bori, Kukdi River } & 3 & 10 & $0.92 \pm 0.02$ & $7.26 \pm 0.34$ & $1.60 \pm 0.04$ \\
\hline & Mean & 40 & $0.910 \pm 0.015$ & $7.447 \pm 0.239$ & $1.571 \pm 0.022$ \\
\hline \multicolumn{6}{|l|}{ Son valley } \\
\hline UT1071; Son valley & 3 & 11 & $0.87 \pm 0.04$ & $7.88 \pm 0.47$ & $1.58 \pm 0.06$ \\
\hline UT1134; Son valley & 2 & 5 & $0.89 \pm 0.04$ & $7.59 \pm 0.54$ & $1.53 \pm 0.08$ \\
\hline UT1134; Son valley & 3 & 9 & $0.90 \pm 0.04$ & $7.91 \pm 0.63$ & $1.67 \pm 0.06$ \\
\hline UT1135; Son valley & 2 & 11 & $0.90 \pm 0.02$ & $7.97 \pm 0.36$ & $1.60 \pm 0.06$ \\
\hline UT1135; Son valley & 3 & 10 & $0.85 \pm 0.03$ & $8.32 \pm 0.66$ & $1.65 \pm 0.06$ \\
\hline UT1136; Son valley & 2 & 10 & $0.92 \pm 0.03$ & $7.97 \pm 0.43$ & $1.54 \pm 0.04$ \\
\hline UT1137; Son valley & 2 & 9 & $0.94 \pm 0.03$ & $7.54 \pm 0.46$ & $1.61 \pm 0.06$ \\
\hline UT1138; Son valley & 2 & 9 & $0.94 \pm 0.03$ & $8.26 \pm 0.54$ & $1.59 \pm 0.04$ \\
\hline UT1359; Ramnagar, Son valley & 3 & 11 & $0.88 \pm 0.04$ & $7.87 \pm 0.52$ & $1.56 \pm 0.04$ \\
\hline KTL-SS-03; Khuteli, Son valley & 6 & 22 & $0.893 \pm 0.030$ & $7.833 \pm 0.270$ & $1.811 \pm 0.058$ \\
\hline GGR-SS-03; Ghogara, Son valley & 6 & 14 & $0.916 \pm 0.034$ & $7.602 \pm 0.326$ & $1.734 \pm 0.053$ \\
\hline \multirow[t]{3}{*}{ GGR-SS-04; Ghogara, Son valley } & 6 & 28 & $0.863 \pm 0.030$ & $7.726 \pm 0.261$ & $1.690 \pm 0.025$ \\
\hline & Mean 1 & 85 & $0.902 \pm 0.010$ & $7.905 \pm 0.163$ & $1.586 \pm 0.017$ \\
\hline & Mean 2 & 147 & $0.895 \pm 0.009$ & $7.819 \pm 0.115$ & $1.636 \pm 0.013$ \\
\hline \multicolumn{6}{|l|}{ Purna valley } \\
\hline UT1070; Purna valley & 2 & 9 & $0.86 \pm 0.02$ & $7.82 \pm 0.22$ & $1.57 \pm 0.03$ \\
\hline UT1070; Gandhigram, Purna River & 3 & 25 & $0.87 \pm 0.03$ & $7.52 \pm 0.28$ & $1.61 \pm 0.04$ \\
\hline \multirow[t]{2}{*}{ UT1361; Purna } & 3 & 11 & $0.88 \pm 0.02$ & $7.32 \pm 0.28$ & $1.61 \pm 0.05$ \\
\hline & Mean & 45 & $0.870 \pm 0.013$ & $7.599 \pm 0.147$ & $1.589 \pm 0.022$ \\
\hline \multicolumn{6}{|l|}{ Narmada valley } \\
\hline UT1069; Narmada valley & 2 & 9 & $0.86 \pm 0.03$ & $7.74 \pm 0.54$ & $1.56 \pm 0.05$ \\
\hline UT1069; Pawlaghat, Narmada River & 3 & 17 & $0.86 \pm 0.02$ & $7.36 \pm 0.24$ & $1.60 \pm 0.03$ \\
\hline \multirow[t]{2}{*}{ UT1299; Guruwara, Narmada } & 3 & 10 & $0.86 \pm 0.04$ & $7.99 \pm 0.55$ & $1.55 \pm 0.04$ \\
\hline & Mean & 36 & $0.860 \pm 0.015$ & $7.501 \pm 0.204$ & $1.578 \pm 0.022$ \\
\hline \multicolumn{6}{|l|}{ Kurnool/Jwalapuram } \\
\hline UT1300; Kurnool & 3 & 10 & $0.88 \pm 0.04$ & $7.21 \pm 0.32$ & $1.58 \pm 0.06$ \\
\hline JWP-17; Jwalapuram & 6 & 13 & $0.867 \pm 0.030$ & $7.759 \pm 0.416$ & $1.501 \pm 0.035$ \\
\hline \multirow[t]{2}{*}{ JLP3-18S; Jwalapuram } & 6 & 27 & $0.874 \pm 0.024$ & $7.428 \pm 0.302$ & $1.443 \pm 0.029$ \\
\hline & Mean & 50 & $0.873 \pm 0.017$ & $7.420 \pm 0.194$ & $1.480 \pm 0.021$ \\
\hline \multicolumn{6}{|l|}{ Other } \\
\hline UT1358; Pitha, Mahanadi & 3 & 11 & $0.87 \pm 0.02$ & $7.63 \pm 0.47$ & $1.66 \pm 0.07$ \\
\hline UT1362; Goguparhu & 3 & 19 & $0.89 \pm 0.02$ & $7.91 \pm 0.40$ & $1.54 \pm 0.04$ \\
\hline
\end{tabular}

Data are presented using the same format, and calculations follow the same method, as for table 1. The resulting estimation of mean values for geochemical parameters, along with other reasoning discussed in the text, permits discrimination of most sites regarding the Toba eruption that produced each of the tephra deposits, provided enough individual glass shards have been analysed to give good statistics. Two mean values have been calculated for the Son valley dataset, using all data (mean 2) and excluding the data from reference 6 (Petraglia et al 2007) (mean 1), to demonstrate the stability of the mean values when large numbers of glass shards have been analysed.

Reference source 6 is table S1 in the online supplement of Petraglia et al (2007). The data from this table, consisting only of mean values, not analyses of individual samples, have been processed the same way as for references 2 and 3 (see caption to table 1), except that the percentages by weight of $\mathrm{FeO}$ have been recalculated to $100 \%$ on a volatile-free basis.

the River Karha, a tributary of the Krishna, which flows eastward into the Bay of Bengal. Bori, north of Pune, adjoins the River Kukdi, another tributary of the Krishna. Gandhigram adjoins the River Purna, a tributary of the Tapti, which flows westward into the Arabian Sea. Simbhora adjoins the River Wardha, a tributary of the Godavari, which flows eastward into the Bay of Bengal. Pawla adjoins the River Narmada, which flows westward into the Arabian Sea. Three of these sites (Bori, Gandhigram, and Pawla) have previously yielded dating evidence and/or tephra samples that have 
been subjected to geochemical analysis (see above and table 3 ).

The attempted Ar-Ar dating by Mishra et al (1995) established that the bulk of the each sample (in terms of ${ }^{39} \mathrm{Ar}$ release) would consist of material with a Pleistocene apparent age, presumably derived from Toba, whereas a small proportion would yield a much greater apparent age. Given that tephras can be produced by entrainment of country rock into the ejecta from volcanic eruptions (e.g., Heiken 1972), in principle, the contamination might indicate such a mode of origin. The country rock in the Toba area consists of Palaeozoic metasediments including metamorphosed limestone (e.g., Aldiss and Ghazali 1984; Barber and Crow 2005). It has indeed been suggested (Dehn et al 1991) that differential inclusion of such material may have influenced the composition of the Toba tephras (i.e., inclusion of limestone may have increased their calcium content), although this has been envisaged as occurring by absorption of country rock into the magma rather than by entrainment within the eruption blast. Dehn et al (1991) concluded that the compositions of the Toba tephras deposited on the floor of the Indian Ocean relate to conditions within the Toba magma chamber. This deduction has been confirmed by analysis of shards of Toba tephra from Bori in India by Karmalkar et al (1998); these authors established that textural characteristics of these glass shards relate to conditions within the Toba magma chamber. Furthermore, these characteristics indicate that the temperature of the magma chamber was $>850^{\circ} \mathrm{C}$, making retention of excess or 'inherited' argon in the shards unlikely.

Previous work anyway suggests that the Toba tephras in India are not primary airfall tuffs; they have been fluvially reworked prior to emplacement in their present locations. This is apparent from their dispositions, in pockets with thicknesses of up to several metres (e.g., Mishra et al 1995; Jones and Pal 2009), whereas the tephras reported beneath the Indian Ocean, which have not been reworked, are no more than a few tens of centimetres thick (e.g., Dehn et al 1991). Mishra et al (1995) nonetheless argued that distances of fluvial transport must have been short, given the angularity of the glass shards, although photomicrographs (e.g., Karmalkar et al 1998) provide evidence of abrasion and possible chemical corrosion of their surfaces. This fluvial transport might well have also resulted in mixing of the material derived from Toba with other material of local origin. One possibility is, therefore, that the contamination is derived from the local bedrock. Another possibility, which we briefly consider after having established that the preferred origin of our tephra samples was Toba eruption D, is that it may have originated from the impact event that produced the latest Early Pleistocene Australasian tektite field (cf. Glass and Koeberl 2006; figure 1).

From the foregoing, it was anticipated at the outset of our analysis, that our tephra samples would consist of mixtures of volcanic and detrital components (e.g., clay), the volcanic component itself being a mixture of rhyolitic glass derived from Toba and a small proportion of contaminant material (including rhyolitic glass) that either became mixed with the material from Toba during fluvial transport or (notwithstanding the earlier discussion) became mixed with the tephra as a result of entrainment of country rock at the eruption source. From table 3 , it was anticipated that the Toba-derived component of the rhyolitic glass would have a $\mathrm{K} / \mathrm{Ca}$ ratio of $\sim 7$, corresponding to a $\mathrm{K}_{2} \mathrm{O} / \mathrm{CaO}$ ratio (by weight) of $\sim 6$. The possibility thus exists that sample splits of the Ar-Ar analysis in which the contaminant is concentrated might be distinguished on the basis that its $\mathrm{K} / \mathrm{Ca}$ ratio is different.

It was also anticipated that particle size could provide a basis for discrimination between these sources, the expectation being that glass shards that have been atmospherically transported from Toba would be concentrated around a particular size. Toba tephras recovered from the floor of the central Indian Ocean, $1000 \mathrm{~km}$ from their source, contain glass shards with a size range of $\sim 50-$ $150 \mu \mathrm{m}$, the typical median size being $\sim 75 \mu \mathrm{m}$ (Dehn et al 1991). It is expected that further dispersal to a point $\sim 3000 \mathrm{~km}$ from the source, the approximate distance to the sites in India (figure 1 ), would have resulted in an approximate halving of the particle size (e.g., Fisher 1964; Walker 1971). One might thus expect, a priori, a particle size distribution of $\sim 25-75 \mu \mathrm{m}$, with a median size of $\sim 40 \mu \mathrm{m}$. However, because tephra dispersal is a highly variable process (e.g., Fisher 1964), it seemed prudent to investigate different particlesize fractions of the tephras to determine which contains the greatest concentration of material from Toba.

\subsection{Initial $K-A r$ analysis}

As an initial test, therefore, the samples were sieved to extract material in the $125-250 \mu \mathrm{m}$ and $63-$ $125 \mu \mathrm{m}$ size fractions and the apparent ages of the separates were determined using the spiked $\mathrm{K}$-Ar method (table 4). In all cases the larger of these size fractions yielded pre-Pleistocene apparent ages for all samples, whereas the smaller one yielded younger apparent ages, including Pleistocene apparent ages for two of the samples. This test thus supports the initial assumption, that the samples contain mixtures of Toba material with small proportions of more ancient 'contaminant'. 
Table 4. Results of initial K-Ar analysis.

\begin{tabular}{lcccccc}
\hline Sample & $\begin{array}{c}\text { Size fraction } \\
(\mu \mathrm{m})\end{array}$ & $\begin{array}{c}\text { Mass } \\
(\mathrm{g})\end{array}$ & $\begin{array}{c}{\left[\mathrm{K}_{2} \mathrm{O}\right]} \\
(\mathrm{wt} \%)\end{array}$ & $\begin{array}{c}{\left[{ }^{40} \mathrm{Ar} *\right]} \\
(\text { atoms })\end{array}$ & $\begin{array}{c}{\left[{ }^{40} \mathrm{Ar} \text { atm }\right]} \\
(\%)\end{array}$ & $\begin{array}{c}\text { Age }( \pm 1 \sigma) \\
(\mathrm{ka})\end{array}$ \\
\hline MRG & $125-250$ & 0.029 & 0.84 & $6.936 \times 10^{13}$ & 85.1 & $33060 \pm 2780$ \\
MRG & $63-125$ & 0.030 & 3.06 & $2.159 \times 10^{13}$ & 85.5 & $2750 \pm 140$ \\
BRI & $125-250$ & 0.022 & 1.83 & $2.282 \times 10^{13}$ & 85.1 & $6550 \pm 580$ \\
BRI & $63-125$ & 0.030 & 3.51 & $1.527 \times 10^{13}$ & 86.8 & $1740 \pm 150$ \\
WRD & $125-250$ & 0.030 & 1.34 & $5.605 \times 10^{13}$ & 72.0 & $16280 \pm 1480$ \\
WRD & $63-125$ & 0.030 & 3.46 & $2.273 \times 10^{13}$ & 84.1 & $2550 \pm 30$ \\
GND & $63-125$ & 0.030 & 4.25 & $1.052 \times 10^{13}$ & 86.3 & $970 \pm 170$ \\
PWL & $125-250$ & 0.030 & 2.79 & $1.337 \times 10^{15}$ & 8.8 & $179830 \pm 15420$ \\
PWL & $63-125$ & 0.029 & 4.02 & $1.309 \times 10^{14}$ & 35.9 & $12920 \pm 1760$ \\
\hline
\end{tabular}

Given the expected concentration of the Toba material in the particle size range $\sim 25-75 \mu \mathrm{m}$ (see above), the range of apparent ages suggests that the contaminant is not likewise concentrated, but is more evenly distributed across a wider range of particle size. The contaminant thus comprises higher proportions of the 125-250 $\mu$ m size fractions than of the $63-125 \mu \mathrm{m}$ size fractions. This suggests that this contaminant has not experienced the filtering effect of prolonged atmospheric transport, which therefore favours a local origin.

In an attempt to understand the nature of this contamination, we recall that the basement of peninsular India, beneath the Deccan Traps, consists of cratonic Archaean crustal nuclei that became sutured together during the Proterozoic era. Most of the outcrop in these Proterozoic 'mobile belts' consists of rhyolitic tephra; examples include the $\sim 750$ Ma Malani Rhyolite of Rajasthan, NW of the Deccan Traps (e.g., Bhushan 2000 ), and the 1000 Ma Sukhda Tuff, east of the Deccan igneous province (e.g., PatranabisDeb et al 2009). For example, northeast of the Deccan Traps in the vicinity of Jabalpur, within sediments of the Semri Group (part of the sedimentary succession of the Vindhyan Basin), there is an outcrop of Proterozoic porcellanites, including rhyolitic glass shards, dated to $\sim 1630 \mathrm{Ma}$ (Chakrabarti et al 2007). It is evident that mixing of even an infinitesimal proportion of such material with Toba material in any of our samples would result in a numerical age that would greatly exceed the true age of the causative Toba eruption. In principle, another possible source of the contaminant might be from the Deccan Traps; although these are predominantly basaltic, there are subsidiary rhyolitic flows, which consist of significant proportions of rhyolitic glass (e.g., Sukheswala and Poldervaart 1958; Bose 1972). However, these rhyolites are predominantly located at the western margin of the Deccan igneous province, bordering the Arabian Sea (near Mumbai and in Gujarat); thus, any rhyolitic material that has reached our sample sites must (like the material derived from Toba) have experienced aeolian transport followed by fluvial reworking. Furthermore, the younger age of the Deccan Traps ( $\sim 65 \mathrm{Ma})$ would require much higher percentages of contamination in our samples, and would be unable to account for any sample split with an apparent age older than $\sim 65 \mathrm{Ma}$ (cf. table 4 ). Figure 4 illustrates estimates of the percentages of contaminantion in different sample splits, assuming a nominal 1000 Ma age for the contamination.

\subsection{Follow-up $K-$ Ar analysis}

A second test was then undertaken, in which each of the samples was sieved to progressively lower mesh sizes, below those previously investigated, followed by $\mathrm{K}-\mathrm{Ar}$ dating. This was to determine whether the trend apparent from the previous test, of a progressive increase in the proportion of Toba material as mesh size decreased, continued to smaller mesh sizes. It was found (table 5) that this was not so; as mesh size decreased the proportion of Toba material (indicated by both the percentage by weight of $\mathrm{K}_{2} \mathrm{O}$ and the apparent age of each sample) also decreased. The natural sorting effect of airborne transport of the Toba ash has thus resulted in optimal size fractions for maximum concentrations of this material in the Indian samples. Comparison of the apparent ages of the sample splits in tables 4 and 5 indicates that for samples MRG, BRI and PWL, the highest proportion of Toba-derived material was in the 53-61 $\mu \mathrm{m}$ size fraction; for sample WRD, the 53$61 \mu \mathrm{m}$ and $63-125 \mu \mathrm{m}$ size fractions contained comparable proportions of Toba-derived material; and for sample GND, the highest proportion of Tobaderived material was in the $63-125 \mu \mathrm{m}$ size fraction (figure 4).

\subsection{Ar-Ar analysis}

A third set of preparations was then undertaken, to facilitate dating using the Ar-Ar method. Material 

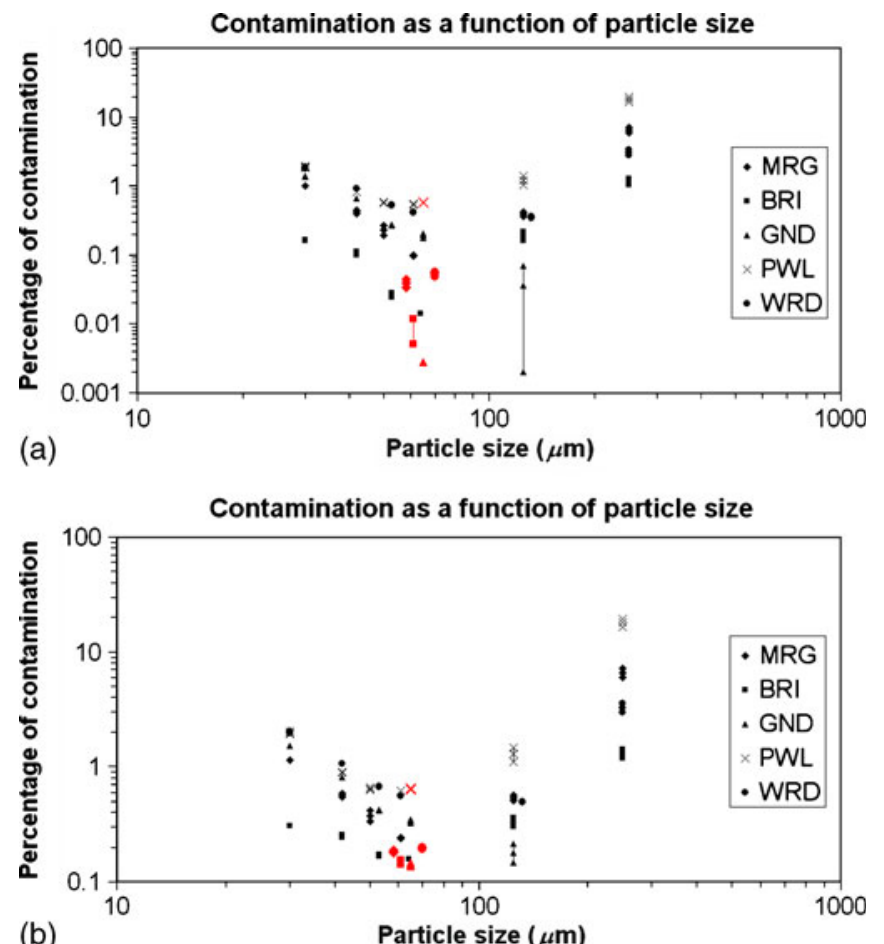

Figure 4. Graphs of the percentage of contamination of the samples as a function of particle size. The horizontal axis is labelled with the upper mesh size for each fraction sieved, although some data points have been displaced horizontally to improve clarity. The calculations apply equation (3) to the data in tables 4 and 5 , with $t_{\mathrm{C}}$ (the age of the contamination) $1000 \mathrm{Ma}$ (i.e., a nominal age within the Proterozoic) and $R_{\mathrm{K}}$ (the relative abundance of $\mathrm{K}_{2} \mathrm{O}$ by weight in the contamination, in comparison with in the material derived from Toba) 0.5. Total fusion ages $( \pm 2 \sigma)$ are also depicted, using enlarged ornament, which is shaded red in the online version. In (a) it is assumed that each sample dates from eruption D of Toba, with $t_{\mathrm{T}}=790 \mathrm{ka}$. In (b) it is assumed that all samples were emplaced by the most recent eruption (i.e., eruption $\mathrm{A} ; t_{\mathrm{T}}=75 \mathrm{ka}$ ). Compilations of data (e.g., Pareek 1981; Bhushan 2000; Das et al 2009) indicate that the Proterozoic rhyolitic tephras of peninsular India have significant geochemical variability; some are potassic, like the Toba tephras, others have lower $\mathrm{K}_{2} \mathrm{O}$ content. Choice of a higher value of $R_{\mathrm{K}}$ would result in a proportionate reduction in the proportion of contamination estimated. Note that the calculations underlying the graphs in this figure and in figure 11 are approximate, for reasons discussed in the text.

that had been sieved to produce the 53-61 $\mu \mathrm{m}$ size fractions for the follow-up $\mathrm{K}-\mathrm{Ar}$ analysis underwent overflow centrifugation using LST, magnetic separation using a Frantz Isodynamic Separator (S.G. Frantz Co. Inc., Tullytown, Pennsylvania), and hand-picking of $\sim 1 \mathrm{~g}$ of purified glass separate under a binocular microscope. The heavy liquid LST (Central Chemical Consulting Pty Ltd., Malaga, Western Australia), used for densitometric separation, is a proprietary lowtoxicity aqueous solution of lithium heteropolytungstates. For reasons of standardization, it was decided to process the same size fraction for each sample, rather than using the $63-125 \mu \mathrm{m}$ size fraction of sample GND, even though the latter size fraction had been shown to contain a higher proportion of Toba-derived material in that particular sample. Furthermore, it was decided not to attempt chemical treatment of the glass shards to remove outer layers that had experienced weathering (effects of weathering being evident from published photomicrographs; Karmalkar et al 1998). It is well known (e.g., Cerling et al 1985) that volcanic glasses can be susceptible to chemical weathering, due to their poorly-defined structure, which frequently results in non-closed-system behaviour. The most widespread effect has been found to be loss of $\mathrm{K}$, which would result in age overestimation as a result of dating using the $\mathrm{K}-\mathrm{Ar}$ system. On the other hand, loss of radiogenic argon can also occur, and would be revealed by apparent ages of the lowest-temperature splits of the argon release that would underestimate the true age of each sample. Clearly, if the potassium loss were in proportion to the argon loss, the analysis would fortuitously reveal a numerical age similar to the true age, even though the material was severely disturbed; however, such a situation could be identified by consideration of the potassium to calcium ratio in each sample split. It was thus envisaged that each sample would consist of a mixture of glass derived from ancient contamination and glass derived from Toba, both types of glass shards consisting of weathered outer and pristine inner components. A further potential problem that can affect $\mathrm{Ar}-\mathrm{Ar}$ dating of glass is loss of ${ }^{39} \mathrm{Ar}$, as a result of recoil during irradiation; this issue is discussed in detail below.

Following irradiation, argon isotopes for both samples and blanks, released by laser step heating, were measured using an Argus multi-collector mass spectrometer operating in static collection mode; the procedures followed are described in more detail by Singer and Pringle (1996), Harford et al (2002) and Mark et al (2009), the laser power being variable in steps between 10 and $60 \mathrm{~W}$. Values of the neutron flux parameter $J$, for the irradiation, were calibrated using the Taylor Creek Rhyolite TCR2a sanidine standard for which an age of $28.34 \pm 0.16 \mathrm{Ma}$ (after Renne et al 1998) was assumed; the estimated uncertainty in each $J$-value is $0.5 \%$. Values of decay constants from Steiger and Jäger (1977) were used. For the current analyses, the argon release from up to 40 heating steps was measured, but for display purposes no more than 25 heating steps, at the lowest power settings, have been reported, the highest temperature splits being invariably of material derived from ancient contamination. For data reduction and display of results, we used ArArCALC version 2.4 (Koppers 2002). 
Table 5. Results of follow-up K-Ar analysis.

\begin{tabular}{|c|c|c|c|c|c|c|c|}
\hline Sample & $\begin{array}{l}\text { Size fraction } \\
\qquad(\mu \mathrm{m})\end{array}$ & $\begin{array}{l}\text { Mass } \\
(\mathrm{g})\end{array}$ & $\begin{array}{l}{\left[\mathrm{K}_{2} \mathrm{O}\right]} \\
(\mathrm{wt} \%)\end{array}$ & $\begin{array}{c}{\left[{ }^{40} \mathrm{~K}\right]} \\
\left(\text { atoms g }{ }^{-1}\right)\end{array}$ & $\begin{array}{c}{\left[{ }^{40} \mathrm{Ar}\right]} \\
\left(\text { atoms } \mathrm{g}^{-1}\right)\end{array}$ & $\begin{array}{c}{\left[{ }^{40} \mathrm{Ar}_{\mathrm{atm}}\right]} \\
(\%)\end{array}$ & $\begin{array}{l}\text { Age } \\
(\mathrm{ka})\end{array}$ \\
\hline MRG & $<30$ & 0.0718 & 2.20 & $3.221 \times 10^{18}$ & $1.0879 \times 10^{9}$ & 82.6 & 5820 \\
\hline MRG & $<30$ & 0.0709 & 2.20 & $3.221 \times 10^{18}$ & $1.0760 \times 10^{9}$ & 83.8 & 5750 \\
\hline MRG & $30-42$ & 0.1020 & 2.60 & $3.803 \times 10^{18}$ & $6.177 \times 10^{8}$ & 89.5 & 2800 \\
\hline MRG & $30-42$ & 0.1004 & 2.60 & $3.803 \times 10^{18}$ & $6.652 \times 10^{8}$ & 89.0 & 3010 \\
\hline MRG & $42-53$ & 0.1023 & 2.96 & $4.332 \times 10^{18}$ & $4.434 \times 10^{8}$ & 90.0 & 1760 \\
\hline MRG & $42-53$ & 0.1015 & 2.96 & $4.332 \times 10^{18}$ & $5.393 \times 10^{8}$ & 88.1 & 2140 \\
\hline MRG & $53-61$ & 0.1004 & 2.96 & $4.790 \times 10^{18}$ & $3.586 \times 10^{8}$ & 91.0 & 1290 \\
\hline MRG & $53-61$ & 0.1015 & 2.96 & $4.790 \times 10^{18}$ & $3.537 \times 10^{8}$ & 91.3 & 1270 \\
\hline BRI & $<30$ & 0.1973 & 3.53 & $5.168 \times 10^{18}$ & $4.806 \times 10^{8}$ & 89.3 & 1600 \\
\hline BRI & $<30$ & 0.1997 & 3.53 & $5.168 \times 10^{18}$ & $4.824 \times 10^{8}$ & 87.8 & 1610 \\
\hline BRI & $30-42$ & 0.1905 & 3.59 & $5.260 \times 10^{18}$ & $4.139 \times 10^{8}$ & 89.1 & 1350 \\
\hline BRI & $30-42$ & 0.1889 & 3.59 & $5.260 \times 10^{18}$ & $3.907 \times 10^{8}$ & 89.2 & 1280 \\
\hline BRI & $42-53$ & 0.1894 & 3.81 & $5.579 \times 10^{18}$ & $3.008 \times 10^{8}$ & 91.0 & 930 \\
\hline BRI & $42-53$ & 0.1890 & 3.81 & $5.579 \times 10^{18}$ & $2.950 \times 10^{8}$ & 90.9 & 910 \\
\hline BRI & $53-61$ & 0.1896 & 3.90 & $5.709 \times 10^{18}$ & $2.844 \times 10^{8}$ & 91.4 & 860 \\
\hline BRI & $53-61$ & 0.1898 & 3.90 & $5.709 \times 10^{18}$ & $2.856 \times 10^{8}$ & 91.2 & 860 \\
\hline WRD & $<30$ & 0.1466 & 2.41 & $3.528 \times 10^{18}$ & $2.0825 \times 10^{9}$ & 84.9 & 10160 \\
\hline WRD & $<30$ & 0.1474 & 2.41 & $3.528 \times 10^{18}$ & $2.0071 \times 10^{9}$ & 83.8 & 9800 \\
\hline WRD & $30-42$ & 0.0758 & 2.91 & $4.263 \times 10^{18}$ & $1.3434 \times 10^{9}$ & 88.0 & 5430 \\
\hline WRD & $30-42$ & 0.0734 & 2.91 & $4.263 \times 10^{18}$ & $1.3389 \times 10^{9}$ & 88.4 & 5410 \\
\hline WRD & $42-53$ & 0.0723 & 3.39 & $4.961 \times 10^{18}$ & $9.813 \times 10^{8}$ & 89.0 & 3410 \\
\hline WRD & $42-53$ & 0.0745 & 3.39 & $4.961 \times 10^{18}$ & $1.003 \times 10^{9}$ & 89.5 & 3480 \\
\hline WRD & $53-61$ & 0.0760 & 3.50 & $5.119 \times 10^{18}$ & $8.502 \times 10^{8}$ & 89.6 & 2860 \\
\hline WRD & $53-61$ & 0.0739 & 3.50 & $5.119 \times 10^{18}$ & $8.541 \times 10^{8}$ & 89.3 & 2870 \\
\hline GND & $<30$ & 0.1993 & 2.65 & $3.879 \times 10^{18}$ & $1.7196 \times 10^{9}$ & 79.9 & 7630 \\
\hline GND & $<30$ & 0.1918 & 2.65 & $3.879 \times 10^{18}$ & $1.7482 \times 10^{9}$ & 81.7 & 7760 \\
\hline GND & $30-42$ & 0.1001 & 3.53 & $5.173 \times 10^{18}$ & $1.2394 \times 10^{9}$ & 83.5 & 4120 \\
\hline GND & $30-42$ & 0.0993 & 3.53 & $5.173 \times 10^{18}$ & $1.2320 \times 10^{9}$ & 83.2 & 4100 \\
\hline GND & $42-53$ & 0.1009 & 3.89 & $5.696 \times 10^{18}$ & $7.229 \times 10^{8}$ & 85.6 & 2190 \\
\hline GND & $42-53$ & 0.0997 & 3.89 & $5.696 \times 10^{18}$ & $7.114 \times 10^{8}$ & 85.5 & 2150 \\
\hline GND & $53-61$ & 0.1004 & 4.08 & $5.971 \times 10^{18}$ & $5.829 \times 10^{8}$ & 85.6 & 1680 \\
\hline GND & $53-61$ & 0.1003 & 4.08 & $5.971 \times 10^{18}$ & $6.240 \times 10^{8}$ & 84.4 & 1800 \\
\hline PWL & $<30$ & 0.0308 & 2.79 & $4.084 \times 10^{18}$ & $4.5640 \times 10^{9}$ & 64.4 & 19240 \\
\hline PWL & $<30$ & 0.0300 & 2.79 & $4.084 \times 10^{18}$ & $4.8394 \times 10^{9}$ & 66.9 & 20400 \\
\hline PWL & $30-42$ & 0.0513 & 3.66 & $5.364 \times 10^{18}$ & $2.8215 \times 10^{9}$ & 71.8 & 9060 \\
\hline PWL & $30-42$ & 0.0494 & 3.66 & $5.364 \times 10^{18}$ & $2.8066 \times 10^{9}$ & 72.9 & 9010 \\
\hline PWL & $42-53$ & 0.0492 & 4.00 & $5.851 \times 10^{18}$ & $2.1755 \times 10^{9}$ & 69.8 & 6400 \\
\hline PWL & $42-53$ & 0.0505 & 4.00 & $5.851 \times 10^{18}$ & $2.2689 \times 10^{9}$ & 70.7 & 6680 \\
\hline PWL & $53-61$ & 0.0513 & 4.15 & $6.077 \times 10^{18}$ & $2.2132 \times 10^{9}$ & 59.6 & 6270 \\
\hline PWL & $53-61$ & 0.0511 & 4.15 & $6.077 \times 10^{18}$ & $2.1953 \times 10^{9}$ & 60.9 & 6220 \\
\hline
\end{tabular}

The above calibrations are each subject to some uncertainty. For example, Renne et al (1998) noted that the Steiger and Jäger (1977) decay constants, use of which is customary in Earth science, differ from values used in nuclear physics research by up to $\sim 2 \%$. Furthermore, Kuiper et al (2004) have proposed, on the basis of cyclostratigraphic dating of tuff beds in the eastern Mediterranean that has yielded ages that can also be calibrated against ArAr dating standards, that the Taylor Creek Rhyolite has an age of $28.53 \pm 0.02 \mathrm{Ma}$, making it $\sim 0.7 \%$ older than for the Renne et al (1998) calibration. Systematic errors of this magnitude have minimal effect on our dating results.

The results obtained from these age determinations are summarized in table 6 and in figures 5-9. The calculation procedure used by ArArCALC sets out to determine four measures of the age for each sample: the total fusion age, a weighted plateau age, and normal and inverse isochron ages. For the latter three age determinations, the procedure uses a statistical algorithm 


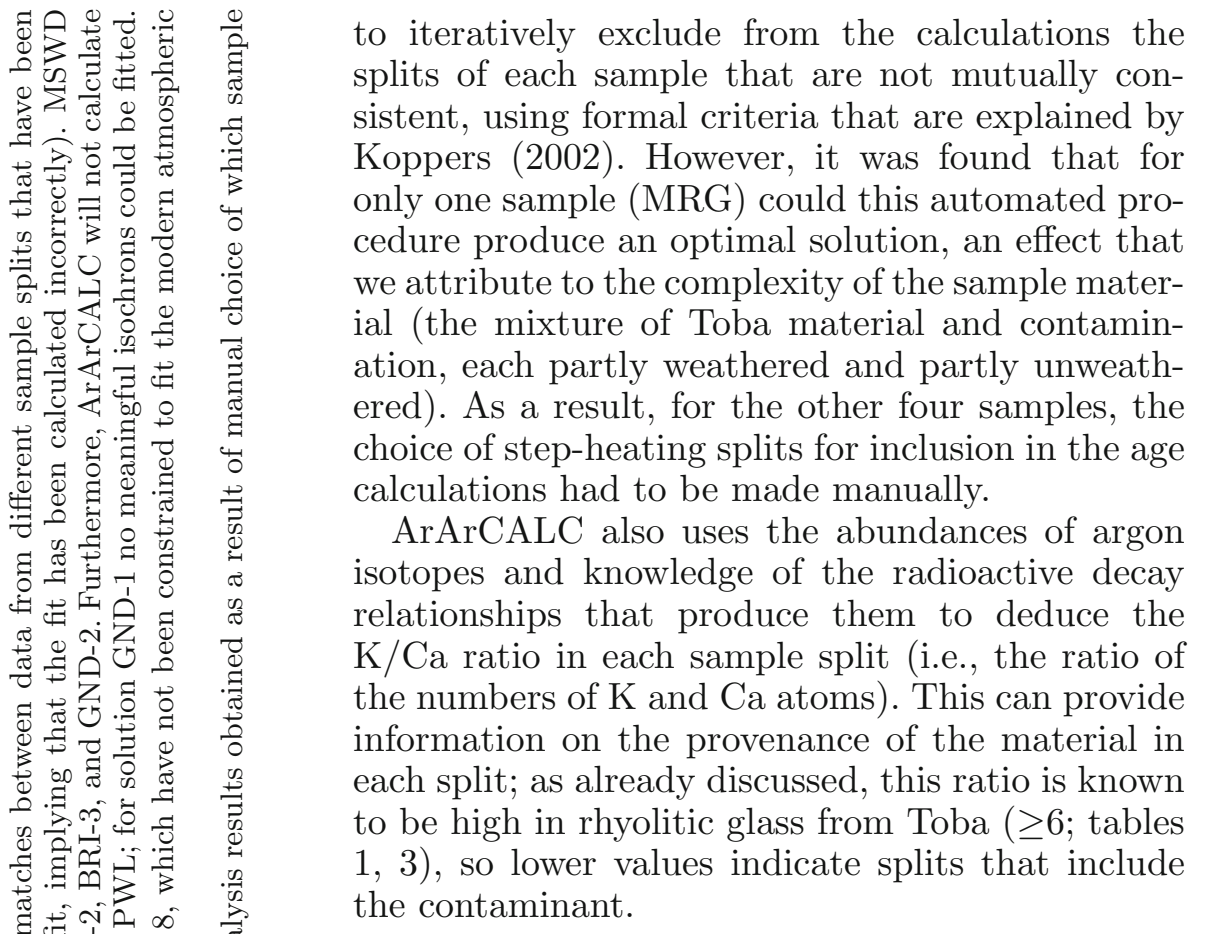

\section{Ar-Ar dating results}

\subsection{Morgaon}

Sample MRG (figure 5), from Morgaon, yielded a total fusion age of $984 \pm 25 \mathrm{ka}( \pm 2 \sigma)$. The procedure used by ArArCALC for fitting an age plateau excluded all but four of the sample splits, resulting in a weighted plateau age, including only the data from these splits, of $560 \pm 54 \mathrm{ka}( \pm 2 \sigma)$. The four included splits came from step-heating at laser power settings of $13.7,14.7,15.7$ and $16.6 \mathrm{~W}$. The two isochrons, fitted through the same data that were used to derive the weighted plateau age, yielded higher ages, but with high uncertainties. This is because the four fitted points plot close together on each of the isochron graphs; furthermore, these graphs have not been constrained to pass through a vertical intercept corresponding with the modern atmospheric ${ }^{40} \mathrm{Ar} /{ }^{36} \mathrm{Ar}$ ratio (295.5). Alternative isochron fits through the same data points and this intercept value, also shown on the graphs but without corresponding age calculations, would yield numerical ages indistinguishable, within error bounds, from the weighted plateau age; each of these alternative isochron fits would pass through all the included data, within error bounds. The four sample splits that contributed to the weighted plateau age have estimated $\mathrm{K} / \mathrm{Ca}$ ratios in the range $\sim 5.8$ to $\sim 6.6$, with a mean of $\sim 6.2 \pm 0.3( \pm 2 \sigma)$, within the range of values appropriate for Toba tephra (tables 1,3 ).

It could thus be tentatively inferred, on this basis, that the event that produced the material 

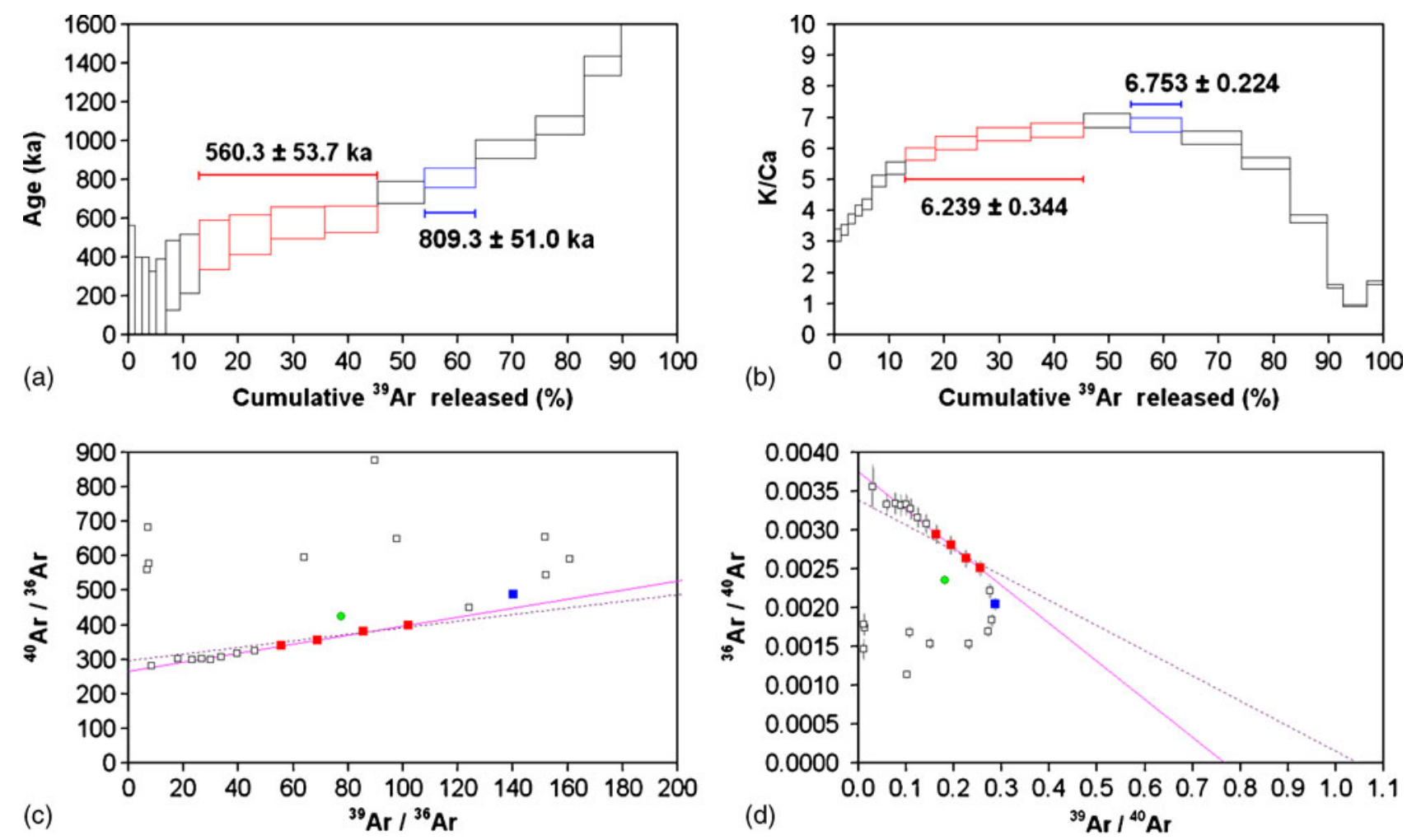

Figure 5. Ar-Ar analysis for Morgaon. (a) Graph showing the apparent ages of step-heating splits and the splits that have been grouped to determine the 'weighted plateau' age for the sample. (b) Graph showing the K/Ca ratio for each of the sample splits as determined from the argon isotope analysis. (c) Normal isochron graph. (d) Inverse isochron graph. In all four parts, red shading highlights the data that contribute to solution MRG-1; blue shading highlights the data that contribute to solution MRG-2 (table 6). In the isochron graphs, green circles mark total fusion points. Solid isochrons are fitted through the highlighted data points, with no constraint on the intercept value indicating the atmospheric ${ }^{40} \mathrm{Ar} /{ }^{36} \mathrm{Ar}$ ratio; dashed isochrons are fitted through the same data and with intercepts at the modern atmospheric value $\left({ }^{40} \mathrm{Ar} /{ }^{36} \mathrm{Ar}=\right.$ 295.5). Isochrons are only fitted if three or more data points contribute. References to colour relate to the online version.

that has been dated was eruption $\mathrm{C}$ in the chronology of Dehn et al (1991). The age assignment deduced from our analysis is slightly high for this interpretation, since Dehn et al (1991) placed the eruption at the MIS 14 to MIS 13 transition, or $\sim 530 \mathrm{ka}$. This site can thus be inferred on this basis to be younger than that deduced by Gaillard et al (2009) and others using magnetostratigraphy. Such a reassignment in age would require the reverse geomagnetic polarities recorded here (Sangode et al 2007) to indicate one or more of the reverse-polarity excursions within the Brunhes chron, rather than the Matuyama chron. Possible candidates are the Big Lost/Emperor and Calabrian Ridge 2/West Eifel excursions, which have ages of $\sim 540$ and $\sim 520$ ka (e.g., Guyodo and Valet 1999).

However, the $\mathrm{K} / \mathrm{Ca}$ ratio deduced from our analysis, $\sim 6.2 \pm 0.3( \pm 2 \sigma)$, is lower than that expected for glass from Toba eruption $\mathrm{C}$ and closer to (but still less than) that expected for eruption D (the expected values being $\sim 8.75 \pm 0.38$ and $8.11 \pm$
0.14 (both $\pm 2 s$ ); table 1 ). This mismatch could indicate loss of potassium from the sample. Loss of potassium as a result of weathering would cause the numerical age to exceed the true age of the sample; it is, therefore, not a feasible explanation for the younger-than-expected numerical age, relative to the existing magnetostratigraphy. However, loss of radiogenic argon would of course cause age underestimation. Furthermore, we note that the step-heating splits of sample MRG with the highest $\mathrm{K} / \mathrm{Ca}$ ratios (indicative of the greatest proportions of Toba material) have higher apparent ages, and that one of these (for laser power 19.6 W, with $\mathrm{K} / \mathrm{Ca} \sim 6.8$ ) has an apparent age of $809.3 \pm 51.0 \mathrm{ka}$ $( \pm 2 \sigma)$, similar to the age of eruption $\mathrm{D}$, providing an alternative candidate age for the sample.

\subsection{Bori}

Sample BRI (figure 6), from Bori, yielded a total fusion age of $815 \pm 34 \mathrm{ka}( \pm 2 \sigma)$. The procedure used by ArArCALC for fitting an age plateau 

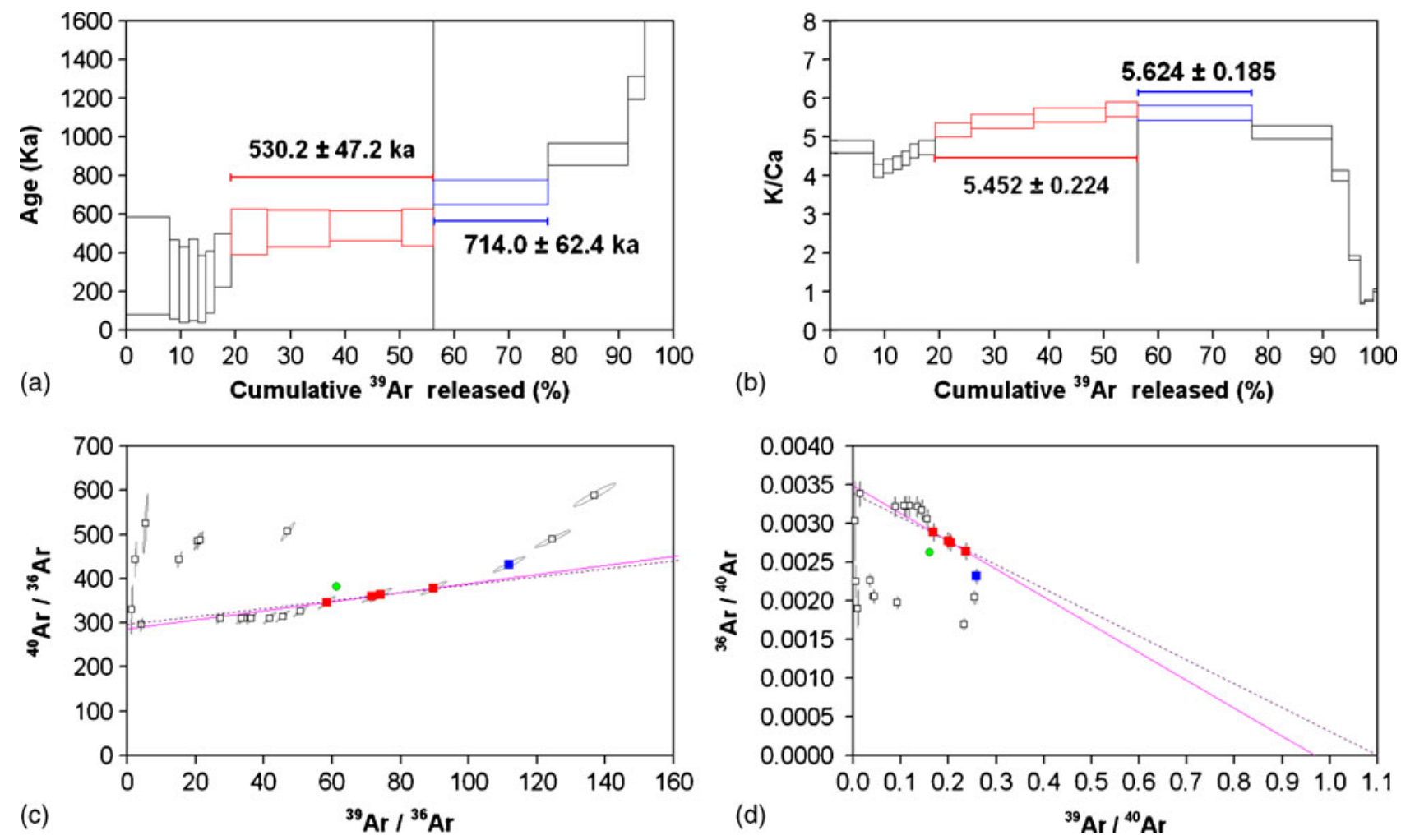

Figure 6. Ar- $\mathrm{Ar}$ analysis for Bori, displayed as for figure 5. Red shading highlights the data that contribute to solution BRI-2; blue shading highlights the data that contribute to solution BRI-3 (table 6). References to colour relate to the online version.
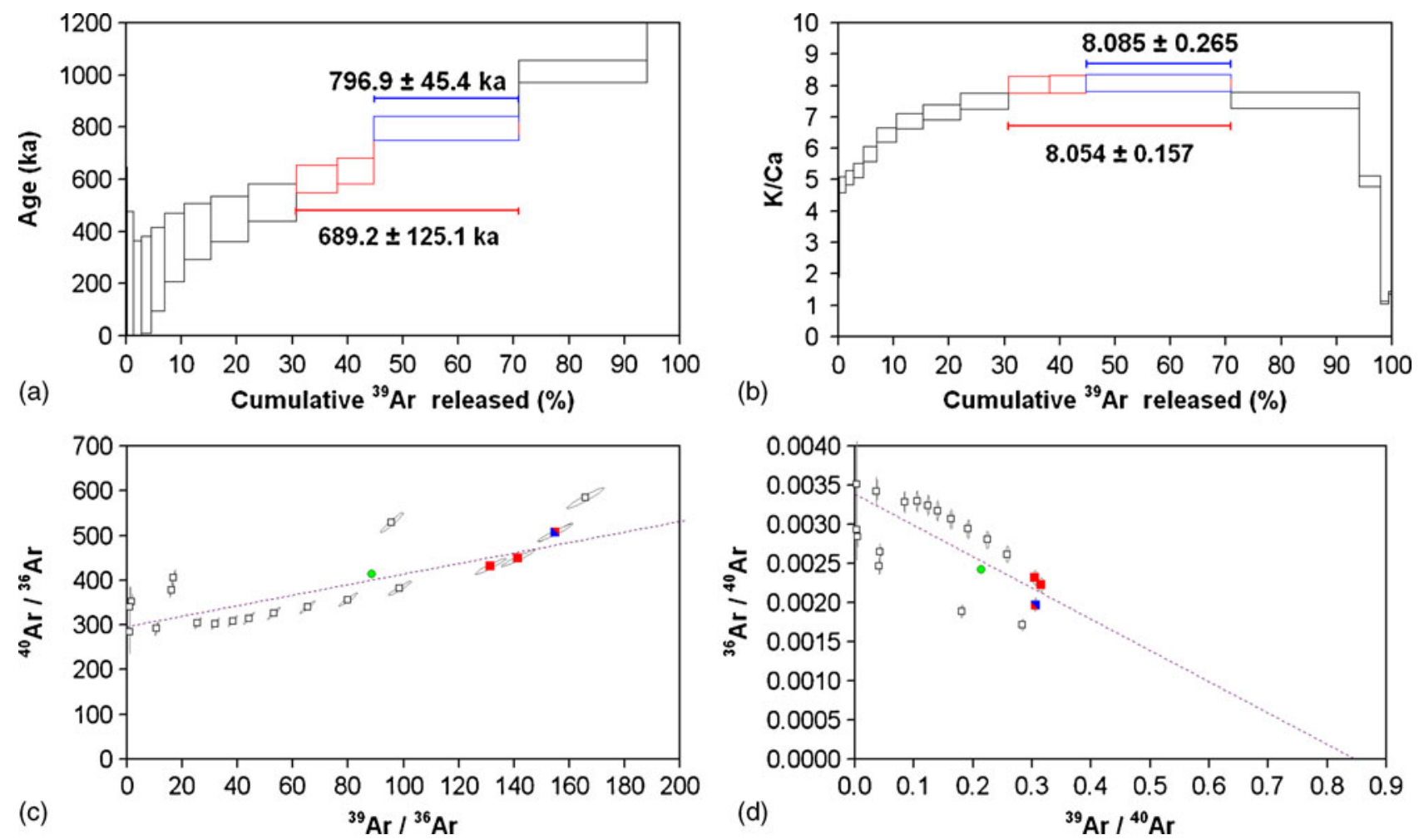

Figure 7. Ar-Ar analysis for Gandhigram, displayed as for figure 5. Red shading highlights the data that contribute to solution GND-1; blue shading highlights the data that contribute to solution GND-2 (table 6). References to colour relate to the online version. 

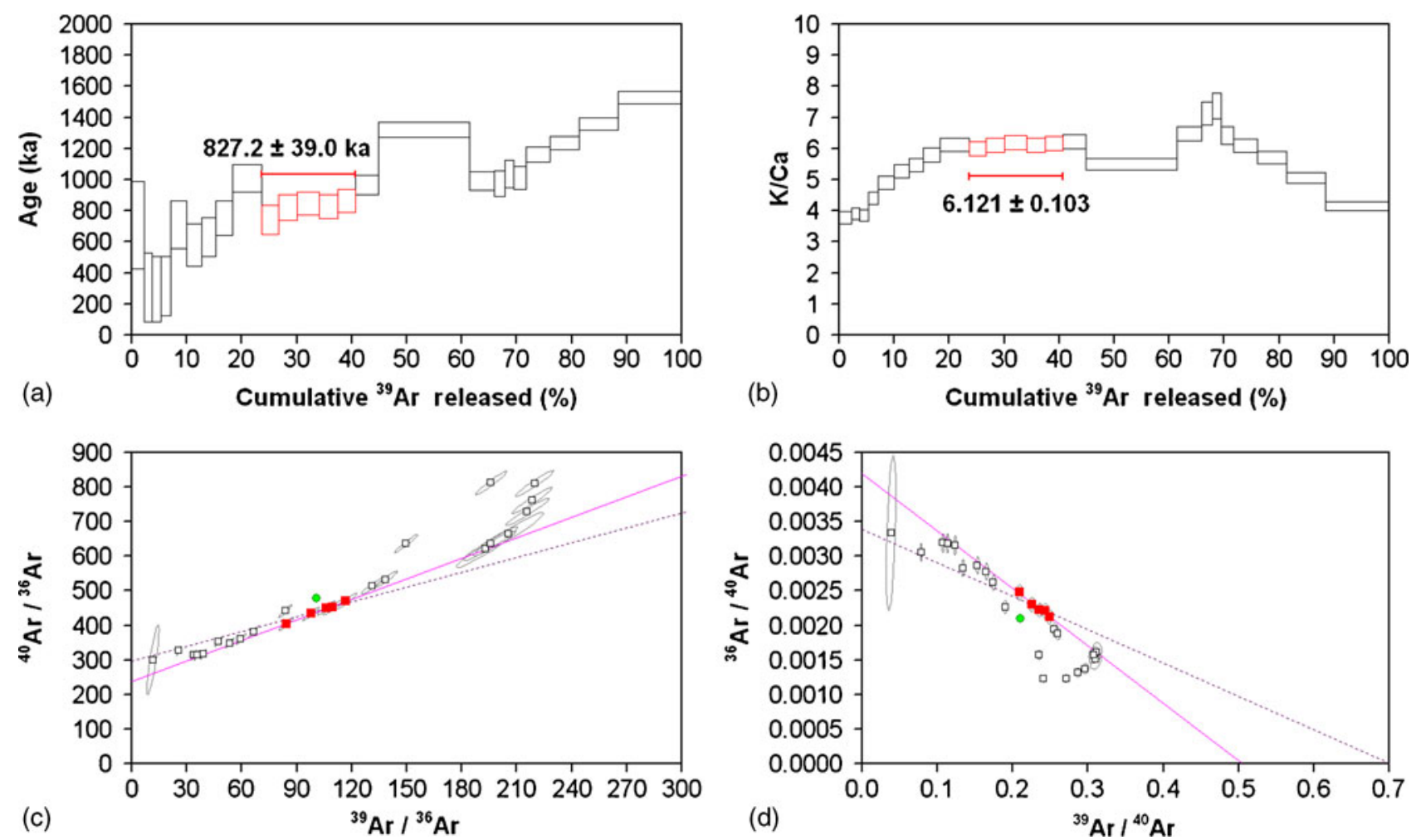

Figure 8. Ar-Ar analysis for Simbhora, displayed as for figure 5. Red shading (in the online version) highlights the data that contribute to solution WRD (table 6).
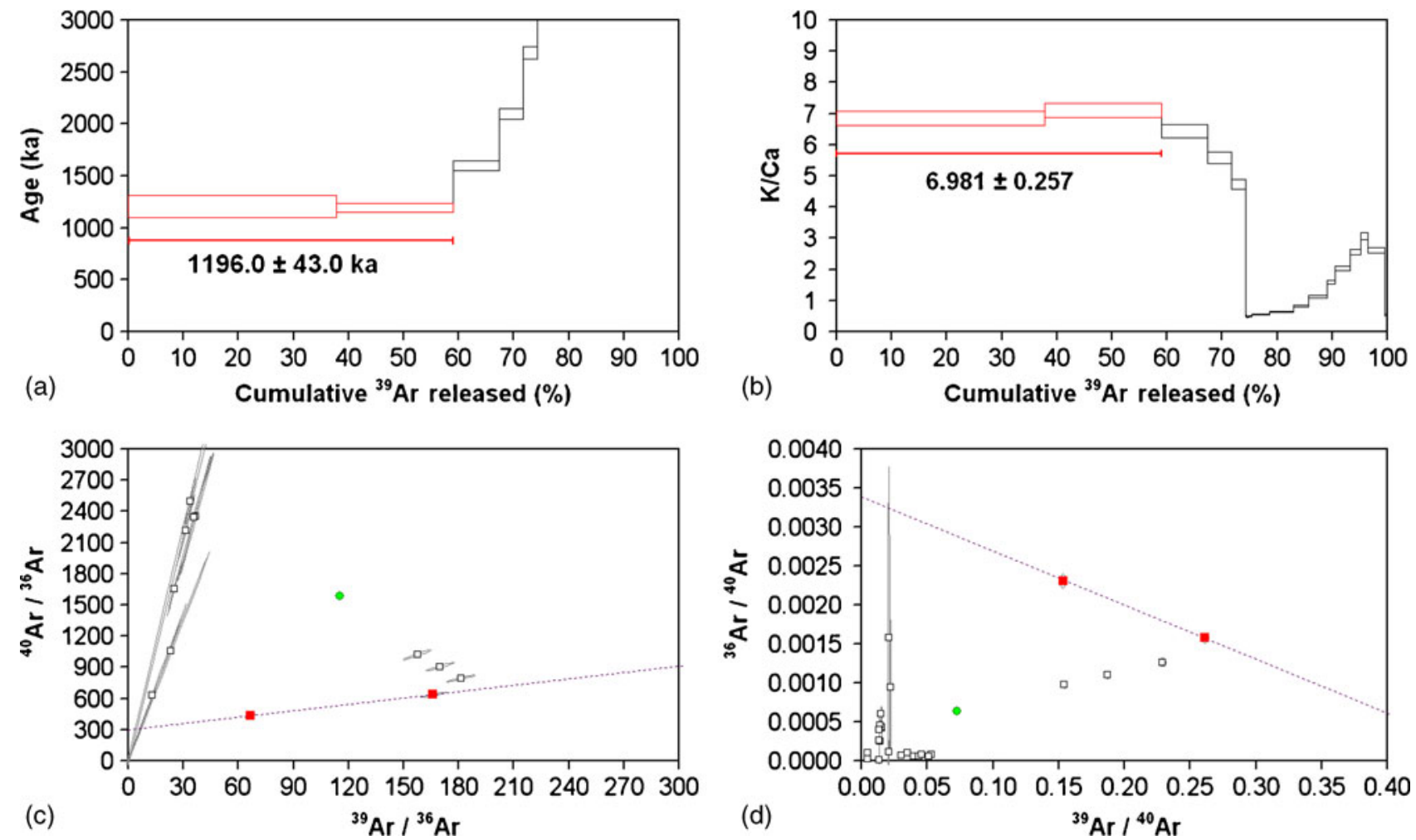

Figure 9. Ar-Ar analysis for Pawla, displayed as for figure 5. Red shading (in the online version) highlights the data that contribute to solution PWL (table 6). 
excluded all but three of the sample splits (retaining those corresponding with laser power settings of $15.3,16.6$ and $17.8 \mathrm{~W}$ ), resulting in a weighted plateau age of $534 \pm 51 \mathrm{ka}( \pm 2 \sigma)$. However, another split (for $13.8 \mathrm{~W}$ laser power) gave concordant results, so the solution was modified by manual intervention to include this split, resulting in an alternative age estimate of $530 \pm 47 \mathrm{ka}$ $( \pm 2 \sigma)$. The isochrons suffer from the same problem as is evident for sample MRG, but would likewise yield numerical ages indistinguishable, within error bounds, from the weighted plateau age if fitted through a vertical intercept corresponding with the modern atmospheric ${ }^{40} \mathrm{Ar} /{ }^{36} \mathrm{Ar}$ ratio. Each of these alternative isochron fits would pass through all the included data, within error bounds. The above weighted plateau age suggests emplacement of the Bori tephra as a result of eruption $\mathrm{C}$ of Toba, ca 530 ka. Furthermore, our numerical age is concordant with the weighted plateau Ar-Ar date obtained by Mishra et al (1995) for their sample $1 \mathrm{~B}$ from Bori (table 2) and with the $\mathrm{K}-\mathrm{Ar}$ date obtained by Horn et al (1993). If this is the true age of the sample, the reverse geomagnetic polarities recorded at Bori (Sangode et al 2007) would presumably indicate a geomagnetic excursion, as was tentatively considered for Morgaon.

The sample splits that have contributed to the weighted plateau ages have $\mathrm{K} / \mathrm{Ca}$ ratios of up to $\sim 5.7$, similar to what is expected for glass from Toba, although (as for sample MRG) less than the value of $\sim 8.75 \pm 0.38$ expected for Toba eruption C (table 1), indicating some disturbance of the $\mathrm{K}$-Ar system. Previous analyses of tephra from the Bori/Kukdi valley area (table 3 ) have yielded a mean $\mathrm{K} / \mathrm{Ca}$ ratio of $7.45 \pm 0.24$ and a mean $\mathrm{FeO}$ content of $0.91 \pm 0.02 \mathrm{wt} \%$ (both $\pm 2 s$ ). This $\mathrm{K} / \mathrm{Ca}$ ratio is higher than the value we have estimated, although still below what is expected (table 1) for eruption $\mathrm{C}$ and, indeed, in better agreement with what is expected for eruption $\mathrm{A}(\sim 7.67 \pm 0.14)$ or eruption $\mathrm{D}(\sim 8.21 \pm 0.15)$, whereas the $\mathrm{FeO}$ content is intermediate between the higher value expected for eruption $\mathrm{C}(\sim 1.00 \pm 0.01 \mathrm{wt} \%)$ and the lower values expected for eruptions $\mathrm{A}$ and $\mathrm{D}$ (both $\sim 0.84 \pm 0.01 \mathrm{wt} \%$ ). However, the compositional variability of tephra $\mathrm{D}$ has already been noted; moreover, it is apparent from comparison of tables 1 and 3 that some analyses of tephra from the Bori area indicate very similar composition to some analyses of tephra D from marine boreholes.

As for sample MRG, we note that high $\mathrm{K} / \mathrm{Ca}$ ratios persist to higher temperature step-heating splits of sample BRI than those included in the above-mentioned age plateau, and these splits also indicate higher apparent ages. The split for laser power $20.5 \mathrm{~W}$ yielded a $\mathrm{K} / \mathrm{Ca}$ ratio of $\sim 5.6$ and an apparent age of $714.0 \pm 62.4 \mathrm{ka}( \pm 2 \sigma)$, close to the age of Toba eruption D. In the light of the above geochemical evidence, we favour this as the preferred age of the sample; this age is indeed concordant with the $670 \pm 60 \mathrm{ka}( \pm 2 \sigma)$ best estimate from use of the Ar-Ar technique by Mishra et al (1995). Moreover, emplacement by eruption $\mathrm{D}$ would readily account for the reversed geomagnetic polarities observed at this site. The underestimation of the true age of the tephra at this site in both our results and those of Mishra et al (1995) can be explained by loss of radiogenic argon as a result of weathering.

\subsection{Gandhigram}

Sample GND (figure 7), from Gandhigram, yielded a total fusion age of $780 \pm 24 \mathrm{ka}( \pm 2 \sigma)$. The procedure used by ArArCALC for fitting an age plateau excluded all but three of the sample splits (those retained correspond with laser power settings of 18.1, 20.1 and $22.5 \mathrm{~W}$ ), resulting in a weighted plateau age of $689 \pm 125 \mathrm{ka}( \pm 2 \sigma)$. However, these three splits have yielded apparent ages that were not mutually concordant, as reflected in the high value of the MSWD parameter for this solution (table 6) and by the fact that no meaningful isochrons could be fitted. Inspection of the data suggests that a better option would be to adopt the age of the sample split for $22.5 \mathrm{~W}$ laser power, $797 \pm 45 \mathrm{ka}( \pm 2 \sigma)$, as the preferred age of the sample. Isochrons fitted through the data points for this split would also pass, within error margins, through the 'total fusion' data point, for which all material in the sample is averaged together.

The $\mathrm{K} / \mathrm{Ca}$ ratio for the included split of sample GND is $\sim 8.1 \pm 0.3$ (table 6 ), roughly as expected for glass from Toba eruption D $(\sim 7.9 \pm 0.4$; table 1 ). On the basis of this and the similarity between our preferred age for sample GND and the age of Toba eruption D (MIS 20-19, or 790 ka; Dehn et al 1991), we deduce that this eruption was responsible for emplacement of the tephra represented at Gandhigram. The tephra from the 'Purna valley' site analysed by Shane et al (1995), which from the limited location information they provided can be presumed to be the same as at Gandhigram, yielded a K/Ca ratio of $\sim 7.8 \pm 0.2( \pm 2 \mathrm{~s})$, in agreement with the value we have estimated and also close to what is expected for eruption D $(\sim 8.21 \pm 0.15( \pm 2 \mathrm{~s}) ;$ table 1$)$. The percentage by weight of $\mathrm{FeO}$ in the 'Purna valley' sample analysed by Shane et al (1995), $0.86 \pm 0.02( \pm 2 \mathrm{~s})$, is also in agreement with what is expected for Toba eruption D $(0.84 \pm 0.01( \pm 2 \mathrm{~s})$; table 1$)$. It is concluded that the material that we have dated is, indeed, derived from Toba, and that the sample 
has yielded a meaningful numerical age, consistent with emplacement as a result of eruption $\mathrm{D}$, ca 790 ka.

\subsection{Simbhora}

Sample WRD (figure 8), from Simbhora, was analysed with a total of 40 heating steps. However, 15 of these for the highest laser power settings (22.7$60 \mathrm{~W}$ ) yielded high apparent ages and low K/Ca ratios, implying that these splits were primarily composed of ancient material. These splits have, therefore, been excluded from the calculation of the total fusion age; the total fusion age thus obtained is $1051 \pm 22 \mathrm{ka}( \pm 2 \sigma)$. The automated procedure used by ArArCALC could not produce a solution for this sample; however, a solution has been obtained by manual selection of the sample splits to be included. Inclusion of the splits for laser powers of 13.0, 13.4, 13.8, 14.2 and $14.4 \mathrm{~W}$ has yielded a weighted plateau age of $827 \pm 39 \mathrm{ka}( \pm 2 \sigma)$. The associated isochrons suffer from the same problem as is evident for other samples, but would likewise yield numerical ages indistinguishable, within error bounds, from the weighted plateau age if fitted through a vertical intercept corresponding with the modern atmospheric ${ }^{40} \mathrm{Ar} /{ }^{36} \mathrm{Ar}$ ratio; each of these alternative isochron fits would pass through all the included data, within error bounds.

The error bounds of the weighted plateau age thus obtained overlap with the ages of Toba eruptions D (MIS 20-19, 790 ka) and E (MIS 21, $\sim 850 \mathrm{ka})$. The estimated $\mathrm{K} / \mathrm{Ca}$ ratio, $\sim 6.1 \pm 0.1$, is higher than expected for eruption $\mathrm{E}(\sim 5.5$; table $1)$ but lower than for eruption $\mathrm{D}(\sim 8.2$; table 1$)$. Since K/Ca ratios from other analysed samples have come out lower than expected, we infer that this sample was emplaced as a result of eruption D; this is in keeping with our conclusion for the age of the Gandhigram/Purna valley tephra (see above).

\subsection{Pawla}

Sample PWL (figure 9), from Pawla, was analysed with a total of 27 heating steps. However, two of these for the highest laser power settings (55 and $60 \mathrm{~W}$ ), which yielded high apparent ages and low $\mathrm{K} / \mathrm{Ca}$ ratios, have been excluded from the analysis; the total fusion age thus obtained for the remainder of the sample is $6517.6 \pm 96.1 \mathrm{ka}$ $( \pm 2 \sigma)$. As for sample WRD, the automated procedure used by ArArCALC could not produce a solution for this sample and so a solution has been obtained by manual selection of sample splits. The splits for laser powers of 12.5 and $12.7 \mathrm{~W}$ (the first two splits analysed, which were jointly responsible for $\sim 60 \%$ of the total release of ${ }^{39} \mathrm{Ar}$ ) yielded a weighted plateau age of $1196.0 \pm 43.0 \mathrm{ka}( \pm 2 \sigma)$. With only two sample splits included, it was not possible for ArArCALC to fit isochrons, although isochrons also fitted to pass through the intercept value corresponding to the modern atmospheric ${ }^{40} \mathrm{Ar} /{ }^{36} \mathrm{Ar}$ ratio pass through both points. However, no large eruption of Toba is known ca $1.2 \mathrm{Ma}$ (Dehn et al 1991 placed eruption F during MIS 46-45, or $\sim 1.4 \mathrm{Ma}$, and eruption E during MIS 21, or $\sim 0.85 \mathrm{Ma}$ ); it is thus concluded that the analysis of this sample has not yielded a meaningful numerical age. A likely cause of this problem is that the two sample splits included in the solution cover such a high proportion of the overall argon release that they mask variations in argon isotopic content similar to those indicated for the other samples (as a result of mixing of Toba material and contamination), for which the analysis began with a laser power of $10 \mathrm{~W}$ rather than $12.5 \mathrm{~W}$.

The K/Ca ratio for the included splits of sample PWL is $\sim 7.0 \pm 0.3( \pm 2 \sigma)$ (table 6$)$, lower than that expected for any of the tephras A, C or D, higher than what is expected for tephra E and roughly in keeping with what is expected for tephra $\mathrm{F}$ (table $1)$. However, given the low $\mathrm{K} / \mathrm{Ca}$ ratios obtained for other samples, we do not attach any significance to this observation. The tephra from the 'Narmada valley' site (table 3) analysed by Shane et al (1995), which from the limited location information they provided can be presumed to correspond with the Pawla site, yielded a $\mathrm{K} / \mathrm{Ca}$ ratio of $\sim 7.7 \pm 0.5( \pm 2 \mathrm{~s})$, which might indicate either tephra A or tephra D (table 1). It is concluded that the material that we have dated is derived from Toba, but we cannot establish which of these candidate eruptions was its source.

We note in passing that the headwaters of the River Narmada, upstream (northeast) of Pawla (figure 2), reach into the outcrop area of the Vindhyan Basin. Rhyolitic glass shards derived from the local Proterozoic volcanism may thus have been fluvially transported to this site, potentially explaining the greater proportion of contamination in sample PWL than in the other samples.

\section{Discussion}

As noted above, recoil of ${ }^{39} \mathrm{Ar}$ nuclei produced by irradiation of ${ }^{39} \mathrm{~K}$ can cause significant systematic errors in Ar-Ar dating (e.g., Turner and Cadogan 1974; Hess and Lippolt 1986; Kelley 2002). Although recoil has not been thoroughly studied in volcanic glasses, it may be significant, as the ${ }^{39}$ Ar nuclei produced by the irradiation may well be less tightly bound than ${ }^{39} \mathrm{Ar}$ nuclei created by irradiation of mineral crystals (Morgan et al 2009; cf. Cerling et al 1985). It is thus important to 

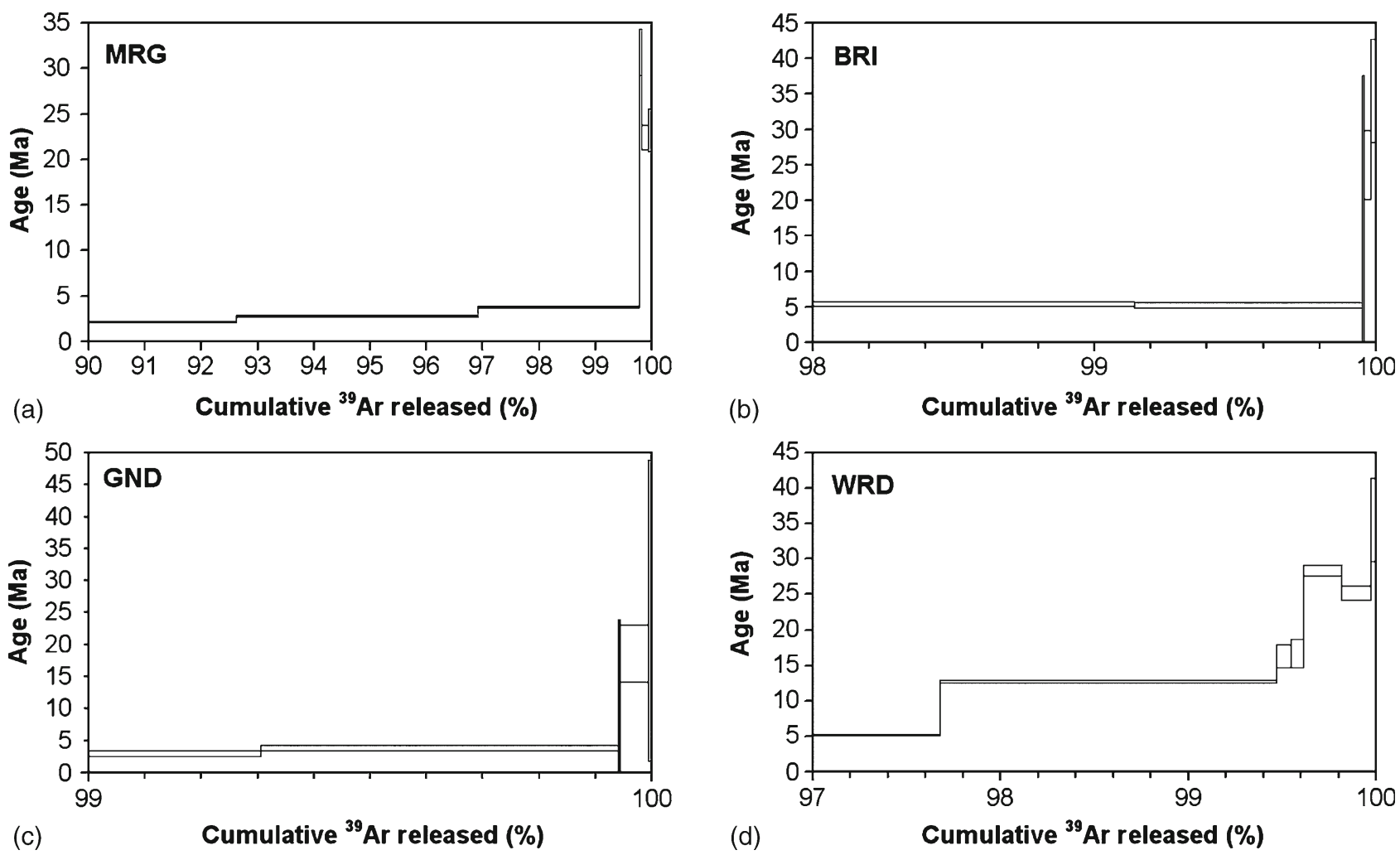

(c)

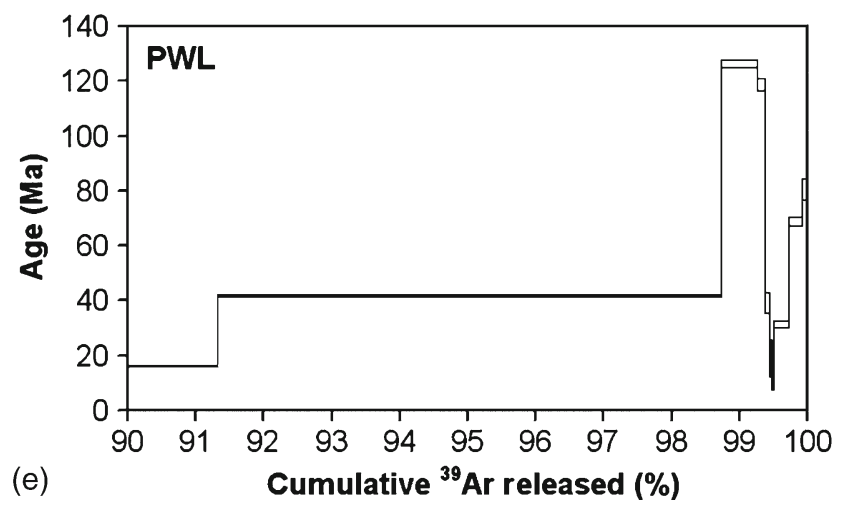

Figure 10. Apparent ages of the highest-temperature splits of each of the samples. Data are plotted using the same display format as for parts (a) of figures 5 to 9 but scaled to indicate the apparent ages deduced for the argon isotopes released during step-heating with the highest laser power settings, which indicate contamination of the samples by ancient material (rhyolitic glass from the Deccan Traps and/or from the Proterozoic crustal basement and/or from microtektite material). See text for discussion.

assess whether this effect may be the cause of the difficulty in obtaining clear age plateaux and/or isochrons for a majority of our sample splits. Recoil of ${ }^{39} \mathrm{Ar}$ nuclei will result in partial loss of the ${ }^{39} \mathrm{Ar}$, the loss being greatest from near the edges of mineral grains, which release argon early in the stepheating sequence. Since ${ }^{39} \mathrm{Ar}$ is a proxy for ${ }^{39} \mathrm{~K}$, such an effect will result in apparent ages that are too old, leading to a decrease in apparent age with step-heating temperature (or laser power). Paine et al (2006) showed that ${ }^{39} \mathrm{Ar}$ loss in biotite is negligible for grain sizes of $\geq 50 \mu \mathrm{m}$; at smaller grain sizes, it becomes increasingly significant, causing true ages to be overestimated by $\sim 10 \%$ for a grain size of $\sim 10 \mu \mathrm{m}$ and by $\sim 25 \%$ for a grain size of $\sim 5 \mu \mathrm{m}$. However, Jourdan et al (2007) showed that the effect is much less in sanidine, where ${ }^{39} \mathrm{Ar}$ recoil loss is $\sim 1 \%$ for a grain size of $\sim 10 \mu \mathrm{m}$ and $\sim 3 \%$ for a grain size of $\sim 5 \mu \mathrm{m}$. Although the material analysed in this study was seived with a 53$61 \mu \mathrm{m}$ mesh, the analysed glass shards will consist mainly of irregularly-shaped fragments derived from bubble-walls (cf. Dehn et al 1991; see also, the photomicrograph illustrations by Karmalkar et al 1998). As a result, they have higher ratios of surface area to volume than would equidimensional grains, 
and so will mimic the behaviour of smaller equidimensional grains. However, correction of any of our apparent ages for loss of ${ }^{39} \mathrm{Ar}$ by recoil, using the equations derived by Jourdan et al (2007) would be impracticable, because this would require information (such as, the typical shape of the grains) that was not measured during the analysis of our samples. Furthermore, it is evident that the principal problem affecting our samples is the observed increase in apparent age with step-heating temperature (figure 10), the opposite effect to what ${ }^{39} \mathrm{Ar}$ loss due to recoil is expected to produce. We are therefore confident that the lack of clear age plateaux in our samples is not caused by ${ }^{39} \mathrm{Ar}$ recoil; as already noted, we favour as the cause the mixing of glass shards derived from Toba with much older glass shards from another source.

Morgan et al (2009) recently presented an $\mathrm{Ar}-\mathrm{Ar}$ analysis of a single sample of Pleistocene tephra from Ethiopia. Analysis of glass shards yielded a seemingly excellent age plateau indicating an age of $\sim 800 \mathrm{ka}$, whereas separate analyses of mineral crystals from the tephra yielded a best estimate age of 150 ka. Although Morgan et al (2009) did not specify the size of their glass shards, from their data this appears to have been $\sim 4000 \mu \mathrm{m}$, reflecting the relative proximity of the source volcano, $\sim 200 \mathrm{~km}$ distant (cf. Fisher 1964; Walker 1971). Morgan et al (2009) concluded that the combination of multiple processes, including elemental mobility within the shards, due to chemical weathering, and/or recoil loss during irradiation, and/or other possible alteration effects, had pervasively affected their sample material. They thus concluded that glassy material of this type is not suitable for Ar-Ar analysis. However, they attributed these particular difficulties to the hydrous nature of their glass shards $\left(\mathrm{H}_{2} \mathrm{O} \sim 7 \%\right)$. In contrast, glass shards from Toba are much less hydrous $\left(\mathrm{H}_{2} \mathrm{O}\right.$ is typically $<1 \%$, often $\ll 1 \%$; e.g., Dehn et al 1991); the issues noted by Morgan et al (2009) may well thus be much less significant in near-anhydrous material such as this.

In this context, it is noteworthy that the $\mathrm{Ar}-$ Ar technique is routinely applied to the dating of tektites, which consist of anhydrous glass of typical rhyolitic composition. For example, Izett et al (1991) dated tektites in the size range 700-1200 $\mu \mathrm{m}$, finding no evidence of disturbance of the material. Lee et al (2004) applied this Ar-Ar technique to tektite material that had been powdered to $125-400 \mu \mathrm{m}$ prior to irradiation; their results likewise provide no indication of any effect of recoil and are consistent within error bounds with independent age estimates. Dallegge and Layer (2004) obtained $\mathrm{Ar}-\mathrm{Ar}$ dates for glass from Cenozoic tephras in Alaska; they found that in some cases, this material yielded meaningful dates whereas other minerals, such as biotite, did not. The preparation by Dallegge and Layer (2004) included sieving to $150-500 \mu \mathrm{m}$ prior to irradiation; although they did not report age plateau and isochron graphs for all their samples, these can be generated from the data in their online supplement and show no indication of any effect of recoil. Our results suggest that meaningful information can be obtained from Ar-Ar dating of anhydrous glassy material with significantly smaller grain sizes than in earlier successful studies.

\subsection{Mixing of rhyolitic glass shards of different ages}

To quantify the effect on the numerical ages obtained for our samples of mixing of radiogenic argon from ancient rhyolitic glass shards with material derived from Pleistocene eruptions of Toba, we note that the equation governing the determination of age, $t$, using the $\mathrm{K}-\mathrm{Ar}$ system (e.g., equation 4.2 of Dalrymple and Lanphere 1969 or equation 1 of Kelley 2002) can be approximated, for material that is much younger than the half-life of ${ }^{40} \mathrm{~K}$ (i.e., no older than several hundred million years), as:

$$
t=A / \lambda K,
$$

where $K$ and $A$ are the measured abundances in the sample of ${ }^{40} \mathrm{~K}$ and radiogenic ${ }^{40} \mathrm{Ar}$ and $\lambda$ is the effective decay constant (the sum of the decay constants for decay of ${ }^{40} \mathrm{~K}$ to ${ }^{40} \mathrm{Ar}$ by electron capture accompanied by gamma photon emission and by electron capture alone). Applying this equation to pure sample material, contaminated sample material, and the contaminant, separately, followed by algebraic substitution, gives (e.g., equation 8.1 of Dalrymple and Lanphere 1969):

$$
t_{\mathrm{A}}=t_{\mathrm{T}}+F R_{\mathrm{K}} t_{\mathrm{C}}
$$

where $t_{\mathrm{A}}$ is the apparent age of a contaminated sample, $t_{\mathrm{T}}$ is the true age of the sample, $F$ is the proportion of contaminant, $R_{\mathrm{K}}$ is the relative abundance of potassium in the contaminant as a fraction of its abundance in the uncontaminated sample, and $t_{\mathrm{C}}$ is the age of the contaminant. Equation (2) can be rearranged to give:

$$
F=\frac{t_{\mathrm{A}}-t_{\mathrm{T}}}{R_{\mathrm{K}} t_{\mathrm{C}}}
$$

as an estimate of the proportion of contamination in the sample. Like equation (1), equation (3) is accurate provided both $t_{\mathrm{T}}$ and $t_{\mathrm{C}}$ are no more than a few hundred million years; otherwise it can serve as an approximation. 

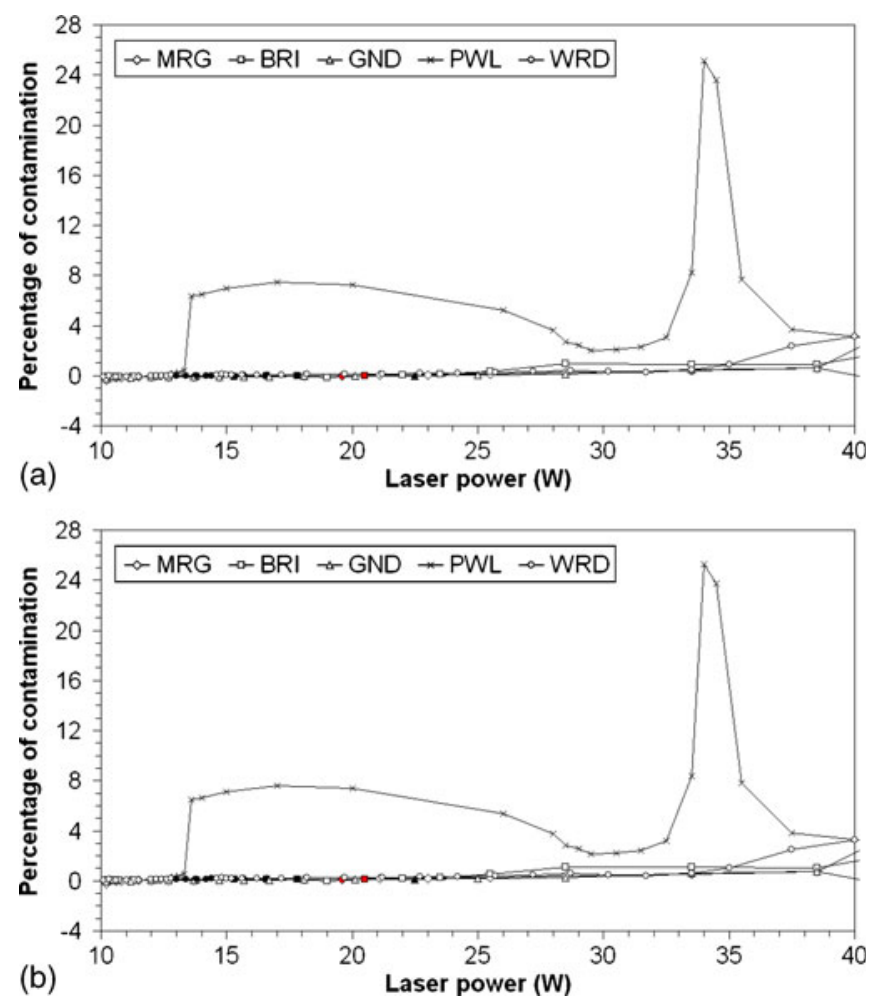

Figure 11. Graphs of the percentage of contamination of the samples as a function of the laser power used in the stepheating analysis. The calculations apply equation (3) to the apparent age values for each of the sample splits (plotted in figures 5 to 10), making the same assumptions regarding parameter values as for figure 4. Data points that contribute to age-determinations in figures 5 to 9 are highlighted using corresponding shades. Parts (a) and (b) reflect the same assumptions regarding the true age of each sample as for the corresponding parts of figure 4. The apparent negative percentages of contamination for some sample splits indicate perturbation of the $\mathrm{K}-\mathrm{Ar}$ system in a manner that is not considered in the calculations (e.g., by weathering, or by ${ }^{39}$ Ar loss due to recoil).

Equation (3) can be used to interpret both the $\mathrm{K}-\mathrm{Ar}$ and $\mathrm{Ar}-\mathrm{Ar}$ dating results from this study (figure 4 and figure 11). As already noted, the $\mathrm{K}$ Ar results (figure 4) indicate a typical progressive increase in concentration of Toba material towards the 53-61 $\mu \mathrm{m}$ size fraction, both from above and from below; we interpret this as an effect of size sorting as a result of atmospheric transport, followed by mixing or contamination with ancient rhyolitic glass. The Ar-Ar results indicate a typical progressive increase in the apparent age of each sample split as laser power increases (i.e., as heating temperature increases). We interpret this as a consequence of the Toba material being more volatile than the older material. This increase in apparent age typically correlates with a decrease in $\mathrm{K} / \mathrm{Ca}$ ratio (figures $5 \mathrm{~b}, 6 \mathrm{~b}, 7 \mathrm{~b}, 8 \mathrm{~b}, 9 \mathrm{~b}$ ), suggesting that the concentration of $\mathrm{K}_{2} \mathrm{O}$ in the contaminant is less than in the Toba material.

\subsection{Implications of our results}

Our study demonstrates that the Ar-Ar technique can extract meaningful information regarding the ages of Toba tephras in India, provided care is taken during sample preparation and provided one undertakes the step-heating analysis using the appropriate range of laser power to vaporize the Toba material without including the less volatile contaminant. Follow-up studies in future will therefore be able to refine our preparation and analysis procedures to further optimize the dating of this difficult material, as well as analysing the Toba tephra from additional sites in India. The weighted mean of our four preferred estimates for the apparent ages of samples (for solutions MRG-2, BRI-3, GND-2 and WRD in table 6) is $798.8 \pm 23.7 \mathrm{ka}( \pm 2 \sigma)$. This can be compared with previous estimates of the age of Toba tephra D, including the $\mathrm{Ar}-\mathrm{Ar}$ date of $799.7 \pm 19.9 \mathrm{ka}( \pm 2 \sigma)$ and the cyclostratigraphic estimate of $788.0 \pm$ $2.2 \mathrm{ka}$, using data from marine boreholes (Hall and Farrell 1995; Lee et al 2004), as well as the $789 \pm 12 \mathrm{ka}( \pm 2 \sigma) \mathrm{Ar}-\mathrm{Ar}$ date for the Oldest Toba Tephra in Sumatra (Izett and Obradovich 1994).

Our analyses demonstrate that step-heating of the samples results in complex argon release spectra. For most of the samples, the initial heating steps encompass an increase in the ${ }^{39} \mathrm{Ar} /{ }^{40} \mathrm{Ar}$ ratio. The highest ${ }^{39} \mathrm{Ar} /{ }^{40} \mathrm{Ar}$ ratios typically correspond with the highest $\mathrm{K} / \mathrm{Ca}$ ratios and mark the greatest concentrations of Toba-derived material; for most samples these splits contribute to our best estimates of the numerical age. At higher laser powers the ${ }^{39} \mathrm{Ar} /{ }^{40} \mathrm{Ar}$ ratio typically decreases, but these splits can be distinguished from those released initially because the latter have lower ${ }^{36} \mathrm{Ar} /{ }^{40} \mathrm{Ar}$ ratios due to the presence of ancient contamination. These patterns are most clearly evident by comparison of the $\mathrm{K} / \mathrm{Ca}$ ratio plots and inverse isochron plots in figures 5, 6, 7 and 9. The principal exception to this general pattern occurs for the sample WRD (figure 8), where the splits that have yielded the preferred age occur within the initial increase in the ${ }^{39} \mathrm{Ar} /{ }^{40} \mathrm{Ar}$ ratio. The splits with the highest ${ }^{39} \mathrm{Ar} /{ }^{40} \mathrm{Ar}$ ratio have apparent ages of $\sim 1 \mathrm{Ma}$, thus most closely comparable to the age of eruption E of Toba. However, we consider it most unlikely that these splits were emplaced as a result of this eruption, because they have much higher $\mathrm{K} / \mathrm{Ca}$ ratios $(\sim 7)$ than the products of this eruption (with $\mathrm{K} / \mathrm{Ca} \sim 5.5$; table 1 ). Additional work, beyond the scope of this study, is required to understand the cause of this difference compared with the other samples.

Pending Ar-Ar dating of further samples, geochemistry can also play a role in assigning other tephra deposits in India to Toba eruptions. For 
example, as already noted the many analyses now available for glass shards from the Son Valley tephra deposits (table 3 ) enable the mean values for geochemical compositions and ratios to be determined with high precision (i.e., with very low standard errors). It is thus apparent that these tephra deposits are more likely derived from eruption D than eruption A (cf. Jones and Pal 2009), notwithstanding the similarity in composition of the products of these two eruptions (table 1). A potential test of this suggestion, for a correlation of tephra deposits with eruption $\mathrm{D}$ at these and other Indian sites, would be the discovery of tektite material from the Australasian impact event, as at Bose in southern China (figure 1). Microtektite from this event has been recovered from beneath both the Bay of Bengal and Arabian Sea (e.g., Prasad et al 2003), but not hitherto from any terrestrial site within India.

We have also considered the possibility that the contamination evident in our samples may be due to mixing with material of tektite origin. Australasian tektite glass typically has rhyolitic composition, with $\mathrm{K}_{2} \mathrm{O} \sim 2-3 \mathrm{wt} \%$ and $\mathrm{K} / \mathrm{Ca} \sim 1$ (e.g., Lee et al 2004, 2009). Moreover, when broken, small ('microtektite') shards (depicted, e.g., by Smit et al 1991) resemble those of rhyolitic glass derived from Toba. However, if this were the correct explanation for the observed contamination, it would require that such microtektite fragments retain inherited (or 'excess') argon. The hypervelocity impact that created this tektite field is envisaged as heating rock fragments to temperatures of $\sim 2000^{\circ} \mathrm{C}$, followed by rapid cooling (on timescales that may be no longer than minutes) as the material is expelled from the atmosphere before falling back to the Earth's surface (e.g., Humayun and Koeberl 2004). Humayun and Koeberl (2004) argued that the lack of significant fractionation of potassium isotopes places bounds on the extent of loss of material by this process from Australasian tektites, although Herzog et al (2005) reported a more complex effect in microtektites, in which material lost from some particles is absorbed into others, thus creating compositional variability without affecting the mean composition. Recent Ar-Ar dating studies of Australasian tektites (by Hou et al 2000; Lee et al 2004) report no evidence of inherited argon in their sample material, although neither publication has documented its dataset in full (they do not report the data that were excluded from age-plateau or isochron fits). However, other studies of tektites, for example that by Izett et al (1991) of the Cretaceous-Tertiary boundary tektite, show excellent age plateaux with no evidence of inherited argon. On the other hand, we are not aware of any attempt to apply the Ar-Ar method for dating Australasian micro- tektites; until this is undertaken one cannot exclude the possibility that they contribute to the contamination in our samples. Isotopic studies indicate that the source rock for the Australasian tektite field was the marine sediment of Jurassic age (e.g., Blum et al 1992; Lee et al 2004), with an estimated numerical age of $\sim 170 \mathrm{Ma}$. In their analysis of microtektites from ODP site 1144 in the South China Sea (figure 1), Glass and Koeberl (2006) reported unmelted mineral fragments of size $>125 \mu \mathrm{m}$, including potassium feldspar that may potentially retain radiogenic argon. There is thus a possibility that the contamination of our samples includes microtektite material, containing inherited argon produced by radioactive decay since the Jurassic; in principle this may explain the $\sim 180 \mathrm{Ma}$ apparent age of the $125-250 \mu \mathrm{m}$ split of sample PWL (table 4) and (as a result of mixing with younger material) the Early Cretaceous ( 120-130 Ma) apparent ages of some step-heating splits of the same sample (figure 10e). Mixing of microtektite material with Toba material, during the fluvial working that has created the tephra deposits in India, would be facilitated by the similarity in age of the two sources. Along with the other potential sources of sample contamination, already discussed, this would add to the complexity of the sample material that makes it so difficult to date. Additional work, beyond the scope of this study, is required to investigate this issue further.

When combined with archaeological evidence, our $\mathrm{Ar}-\mathrm{Ar}$ dating results imply that Acheulian artefacts were in use in peninsular India at the time of Toba eruption D ( 790 ka), providing evidence for human occupation at this time, consistent with the evidence from southern China (Hou et al 2000). We also suggest, on the basis of similarity in geochemistry, that the Son valley tephra marks the same eruption of Toba, implying that the Acheulian artefacts from this river valley have corresponding antiquity. Acheulian artefacts are, of course, found even earlier in southwest Asia; for example, they occur in the Jordan and Euphrates valleys as early as the mid-Early Pleistocene (e.g., Tchernov 1987, 1999; Demir et al 2007, 2008; Martinez-Navarro et al 2009). Moreover, such ages are in broad agreement with the aforementioned dating of the Isampur site in southern India to $1270 \pm 170$ ka (Paddayya et al 2002), which is currently the oldest numerical date for Lower Palaeolithic occupation anywhere in peninsular India. These Early Pleistocene occurrences of 'Large Flake Acheulian' artefacts significantly pre-date the first appearance, in the early Middle Pleistocene, of the Acheulian 'sensu stricto' in western Europe. The earliest well-dated Acheulian artefacts in northwest Europe are those found within the terrace deposit of the River Somme that 
is assigned to MIS 14 (e.g., Antoine et al 2007), although Acheulian artefacts have been reported earlier in Iberia and southern and central France (e.g., Mishra et al 2007). Furthermore, as Petraglia et al (2007) noted, tephra from the $\sim 75$ ka Toba eruption A at Jwalapuram is associated with Middle Palaeolithic artefacts, confirming that it is much younger than the tephras at the other sites that we have investigated.

\section{Conclusions}

Analysis of the geochemistry of shards of rhyolitic glass from tephras at sites in India indicates emplacement by Toba eruption D, $\sim 790 \mathrm{ka}$, rather than eruption $\mathrm{A}, \sim 75 \mathrm{ka}$, as previously suggested, notwithstanding the similarity in the products of these two eruptions. This supports the view (e.g., Mishra and Rajaguru 1994) that some of these tephra exposures are stratigraphically associated with Lower Palaeolithic artefacts and indicate human occupation of peninsular India in the late Early Pleistocene. $\mathrm{K}$-Ar dating of multiple size-fractions of tephra indicates that the material reaching India from Toba is typically concentrated in the $53-61 \mu \mathrm{m}$ size-fraction. However, even in this size-fraction, $\mathrm{K}-\mathrm{Ar}$ dates for all samples exceed the inferred eruption age, indicating the presence of more ancient contamination. Notwithstanding the presence of this contamination and the loss of potassium from some step-heating splits, we show that $\mathrm{Ar}-\mathrm{Ar}$ dating has yielded material with apparent ages of $\sim 790 \mathrm{ka}$ in the tephras from four of our five sites (Morgaon, Bori, Gandhigram and Simbhora). This suggests that the tephras at these sites were emplaced by Toba eruption D, consistent with the evidence from the geochemistry, although the splits that yielded these apparent ages represent no more than $\sim 10-20 \%$ of the argon release in the samples. Our results thus demonstrate that it is feasible, in principle, to date this difficult material using the Ar-Ar technique; as well as analysing the Toba tephra from additional sites in India, future follow-up studies will therefore be able to refine our preparation and analysis procedures to better optimize the dating.

\section{Acknowledgements}

This work was funded by award IP/758/0302 from the Natural Environment Research Council isotope geoscience panel (D.R.B.). The $\mathrm{K}-\mathrm{Ar}$ and $\mathrm{Ar}-\mathrm{Ar}$ analyses were undertaken at the Scottish Universities' Environmental Research Centre; we thank
Paul Alexandre, Dan Barfod, Tony Fallick, Malcolm Pringle, and Fin Stuart for their contributions. We also thank Anthony Koppers for help with installing and configuring the ArArCALC analysis software.

\section{References}

Acharyya S K and Basu P B 1993 Toba ash on the Indian subcontinent and its implications for correlation of Late Pleistocene alluvium; Quat. Res. 40 10-19.

Aldiss D T and Ghazali S A 1984 The regional geology and evolution of the Toba volcano-tectonic depression, Indonesia; J. Geol. Soc. London 141 487-500.

Antoine P, Limondin-Lozouet N, Chaussé C, Lautridou J-P, Pastre J-F, Auguste P, Bahain J-J, Falguères C and Galehb B 2007 Pleistocene fluvial terraces from northern France (Seine, Yonne, Somme): Synthesis, and new results from interglacial deposits; Quat. Sci. Rev. 26 2701-2723.

Barber A J and Crow M J 2005 Pre-Tertiary stratigraphy; In: Sumatra: Geology, Resources and Tectonic Evolution (eds) Barber A J, Crow M J and Milsom J S; Geol. Soc. London, Memoir 31 24-53.

Bassinot F C, Labeyrie L D, Vincent E, Quidelleur X, Shackleton N J and Lancelot Y 1994 The astronomical theory of climate and the age of the Brunhes-Matuyama magnetic reversal; Earth Planet. Sci. Lett. 126 91-108.

Bhushan S 2000 Malani Rhyolites - A review; Gondwana Res. 3 65-77.

Bigazzi G, Bonadonna F P, Laurenzi M A and Tonarini S 1993 A test sample for fission-track dating of glass shards; Nucl. Tracks Radiat. Meas. 21 489-497.

Bigazzi G, Balestriei M L, Norelli P, Oddone M and Tecle T M 2004 Fission-track dating of a tephra layer in the Alat Formation of the Dandiero Group (Danakil Depression, Eritrea); Rivista Italiana di Paleontologia e Stratigrafia 110, suppl. 45-49.

Blum J D, Papanastassiou D A, Koeberl C and Wasserburg G J 1992 Nd and Sr isotopic study of Australasian tektites: New constraints on the provenance and age of target material; Geochim. Cosmochim. Acta 56 483-492.

Blum M D and Straffin E C 2001 Fluvial responses to external forcing: Examples from the French Massif Central, the Texas Coastal Plain (USA), the Sahara of Tunisia, and the lower Mississippi Valley (USA); In: River Basin Sediment Systems: Archives of Environmental Change (eds) Maddy D, Macklin M and Woodward J (Rotterdam: Balkema), pp. 195-228.

Bose M H 1972 Deccan basalts; Lithos 5 131-145.

Bridgland D R and Westaway R 2007 Preservation patterns of Late Cenozoic fluvial deposits and their implications: Results from IGCP 449; Quat. Int. 189 5-38.

Cerling T E, Brown F H and Bowman J R 1985 Low temperature alteration of volcanic glass-hydration, $\mathrm{Na}, \mathrm{K}$, ${ }^{18} \mathrm{O}$, and Ar mobility; Chem. Geol. (Isotope Geoscience Section) $\mathbf{5 2}$ 281-293.

Chakrabarti R, Basu A R and Chakrabarti A 2007 Trace element and Nd-isotopic evidence for sediment sources in the Mid-Proterozoic Vindhyan Basin, central India; Precamb. Res. 159 260-274.

Chauhan P R 2010 Comment on 'Lower and early Middle Pleistocene Acheulian in the Indian sub-continent' by Gaillard et al (2009); Quat. Int. 223-224 248259.

Chen C-H, Meng-Yang, Iizuka Y, Dehn J, Wei K-Y and Carey S 2004 First Toba supereruption revival: Reply; Geology online forum 32 e54-e55. 
Chesner C A, Rose W I, Deino A, Drake R and Westgate J A 1991 Eruptive history of Earth's largest Quaternary caldera (Toba, Indonesia) clarified; Geology 19 200-203.

Colls A E, Stokes S, Blum M D and Straffin E 2001 Age limits on the Late Quaternary evolution of the upper Loire River; Quat. Sci. Rev. 20 743-750.

Dallegge T A and Layer P W 2004 Revised chronostratigraphy of the Kenai Group from ${ }^{40} \mathrm{Ar} /{ }^{39} \mathrm{Ar}$ dating of lowpotassium bearing minerals, Cook Inlet Basin, Alaska; Canadian J. Earth Sci. 41 1159-1179.

Dalrymple G B and Lanphere M A 1969 Potassiumargon Dating: Principles, Techniques and Applications to Geochronology (San Francisco: W.H. Freeman and Company), $258 \mathrm{p}$.

Das K, Yokotama K, Chakraborty P P and Sarkar A 2009 Basal tuffs and contemporaneity of the Chattisgarh and Khariar basins based on new dates and geochemistry; J. Geol. 117 88-102.

Dehn J, Farrell J W and Schminke H-U 1991 Neogene tephrochronology from Site 758 on Ninety East Ridge: Indonesian arc volcanism of the past $5 \mathrm{Ma}$; Proceedings of the Ocean Drilling Program, Scientific Results 121 273-295.

Demir T, Westaway R, Bridgland D, Pringle M, Yurtmen S, Beck A and Rowbotham G 2007 Ar-Ar dating of Late Cenozoic basaltic volcanism in northern Syria: Implications for the history of incision by the River Euphrates and uplift of the northern Arabian Platform; Tectonics 26 TC3012, 30 pp, doi: 10.1029/2006TC001959 [published online].

Demir T, Seyrek A, Westaway R, Bridgland D and Beck A 2008 Late Cenozoic surface uplift revealed by incision by the River Euphrates at Birecik, southeast Turkey; Quat. Int. 186 132-163.

Diehl J F, Onstott T C, Chesner C A and Knight M D 1987 No short reversals of Brunhes age recorded in the Toba tuffs, north Sumatra, Indonesia; Geophys. Res. Lett. 14 $753-756$.

Durrheim R J and Mooney W D 1994 Evolution of the Precambrian lithosphere: Seismological and geochemical constraints; J. Geophys. Res. 99 15,359-15,374.

Fisher R 1964 Maximum size, median diameter, and sorting of tephra; J. Geophys. Res. 69 341-355.

Gaffer P A, Sinha M and Sekar S 2001 Neotectonic activity in Wardha Sub-Basin, Godavari Basin in parts of Amravati and Wardha Districts, Maharashtra. In: National Symposium on the Role of Earth Sciences in Integrated Development and Related Societal Issues; Geol. Surv. India Spec. Publ. 65 235-238.

Gaillard C, Mishra S, Singh M, Deo S and Abbas R 2009 Lower and Early Middle Pleistocene Acheulian in the Indian sub-continent; Quat. Int. 223-224 234-241.

Gaillard C, Mishra S, Singh M, Deo S and Abbas R 2010 Reply to: "Comment on 'Lower and early Middle Pleistocene Acheulian in the Indian sub-continent' by $\mathrm{P}$ Chauhan"; Quat. Int. 223-224 260-264.

Glass B P and Koeberl C 2006 Australasian microtektites and associated impact ejecta in the South China Sea and the Middle Pleistocene supereruption of Toba; Meteor. Planet. Sci. 41 305-326.

Guyodo Y and Valet J-P 1999 Global changes in intensity of the Earth's magnetic field during the past $800 \mathrm{kyr}$; Nature $399249-252$.

Hall C M and Farrell J W 1995 Laser ${ }^{40} \mathrm{Ar} /{ }^{39} \mathrm{Ar}$ ages of tephra from Indian Ocean deep-sea sediments: Tie points for the astronomical and geomagnetic polarity time scales; Earth Planet. Sci. Lett. 133 327-338.
Harford C L, Pringle M S, Sparks R S J and Young S R 2002 The volcanic evolution of Montserrat using ${ }^{40} \mathrm{Ar} /{ }^{39} \mathrm{Ar}$ geochronology. In: The eruption of the Soufrière Hills volcano, Montserrat, from 1995 to 1999 (eds) Druitt T $\mathrm{H}$ and Kojkelaar B P; Geol. Soc. London, Memoir 21 93-113.

Heiken G H 1972 Morphology and petrology of volcanic ashes; Geol. Soc. Am. Bull. 83 1961-1988.

Herzog G F, Alexander C M O'D, Glass B P, Berger E L and Delaney J S 2005 Potassium isotope fractionation in Australasian microtektites: Evidence for evaporation and re-condensation in a vapor plume; 36th Lunar and Planetary Science Conference, abstract no. 1169, 2 p.

Hess J C and Lippolt H J 1986 Kinetics of Ar isotopes during neutron-irradiation: ${ }^{39}$ Ar loss from minerals as a source of error in ${ }^{40} \mathrm{Ar} /{ }^{39} \mathrm{Ar}$ dating; Chem. Geol. $59223-236$.

Horn P, Muller-Solmus D, Storzer D and Zoller L 1993 K-Ar, fission-track and thermoluminescence ages of Quaternary volcanic tuffs and their bearing on Acheulian artefacts from Bori, Kukdi valley, Pune District, India; Zeitschrift der Deutschen Geologischen Gesellschaft 144 326-329.

Hou Y, Potts R, Yuan B, Guo Z, Deino A, Wang W, Clark J, Xie G and Huang W 2000 Mid-Pleistocene Acheulean-like stone technology of the Bose Basin, South China; Science 287 1622-1626.

Humayun M and Koeberl C 2004 Potassium isotopic composition of Australasian tektites; Meteor. Planet. Sci. 39 1509-1516.

Izett G and Obradovich J $1994{ }^{40} \mathrm{Ar} /{ }^{39} \mathrm{Ar}$ age constraints for the Jaramillo Normal Subchron and the MatuyamaBrunhes geomagnetic boundary; J. Geophys. Res. 99 2925-2934.

Izett G A, Dalrymple G B and Snee L W $1991{ }^{40} \mathrm{Ar} /{ }^{39} \mathrm{Ar}$ age of Cretaceous-Tertiary boundary tektites from Haiti; Science 252 1539-1542.

Jones S C 2007 The Toba supervolcanic eruption: Tephra-fall deposits in India and paleoanthropological implications; In: The Evolution and History of Human Populations in South Asia: Inter-disciplinary Studies in Archaeology, Biological Anthropology, Linguistics and Genetics (eds) Petraglia M and Allchin B (Dordrecht, The Netherlands: Springer), pp. 173-200.

Jones S C and Pal J N 2009 The Palaeolithic of the Middle Son valley, north-central India: Changes in hominin lithic technology and behaviour during the Upper Pleistocene; J. Anthropol. Archaeol. 28 323-341.

Jourdan F, Matzel J P and Renne P R $2007{ }^{39} \mathrm{Ar}$ and ${ }^{37}$ Ar recoil loss during neutron irradiation of sanidine and plagioclase; Geochim. Cosmochim. Acta 71 2791-2808.

Kailath A J, Rao T K G, Dhir R P, Nambi K S V, Gogte V D and Singhvi A K 2000 Electron spin resonance characterization of calcretes from Thar Desert for dating applications; Radiat. Meas. 32 371-383.

Karmalkar N R, Ghate S N, Mishra S and Rajaguru S N 1998 Morphology of the volcanic ash from the Kukadi River section, Pune District, Maharashtra; J. Geol. Soc. India $51213-218$.

Kelley S P $2002 \mathrm{~K}-\mathrm{Ar}$ and Ar-Ar dating; Rev. Mineral. Geochem. 47 785-818.

Kuiper K F, Hilgen F J, Steenbrink J and Wijbrans J R $2004{ }^{40} \mathrm{Ar} /{ }^{39} \mathrm{Ar}$ ages of tephras intercalated in astronomically tuned Neogene sedimentary sequences in the eastern Mediterranean; Earth Planet. Sci. Lett. 222 583-597.

Koppers A A P 2002 ArArCALC-software for ${ }^{40} \mathrm{Ar} /{ }^{39} \mathrm{Ar}$ age calculations; Comput. Geosci. 28 605-619.

Korisettar R and Rajaguru S N 1998 Quaternary stratigraphy, palaeoclimate and the Lower Palaeolithic of India; 
In: Early Human Behaviour in Global Context: The Rise and Diversity of the Lower Palaeolithic Record (eds) Petraglia M and Korisettar R (London: Routledge), pp. 304-342.

Korisettar R, Mishra S, Rajaguru S N, Gogte V D, Ganjoo R K, Venkatesan T R, Tandon S K, Somayajulu B L K and Kale V S 1988 Age of the Bori volcanic ash and Lower Palaeolithic culture of the Kukdi valley, Maharashtra; Bull. Deccan College Res. Inst. 48 135-138.

Korisettar R, Venkatesan T R, Mishra S, Rajaguru S N, Somayajulu B L K, Tandon S K, Gogte V D, Ganjoo R K and Kale V S 1989 Discovery of a tephra bed in the Quaternary alluvial sediments of Pune District (Maharashtra), peninsular India; Curr. Sci. 58 564-567.

Lee M-Y, Chen C-H, Wei K-Y, Iizuka Y and Carey S 2004 First Toba supereruption revival; Geology 32 61-64.

Lee Y-T, Chen J-C, Ho K-S and Juang W-S 2004 Geochemical studies of tektites from east Asia; Geochem. J. 38 $1-17$.

Lee Y-T, Huang R-Y, Chen J-C, Shih J-Y, Chang W-F, Hu Y-T and Chen C-C 2009 Geochemistry of tektites from Hainan Island and northeast Thailand; World Acad. Sci. Eng. Technol. 60 839-843.

Li B, Li S-H and Wintle A G 2007 Overcoming environmental dose rate changes in luminescence dating of waterlain deposits; Geochronometria 30 33-40.

Li B, Li S-H, Wintle A G and Zhao H 2008 Isochron dating of sediments using luminescence of K-feldspar grains; Geophys. Res. 113 F02026, 15 pp, doi: 10.1029/2007JF000900 [published online].

Liang X, Wei G, Shao L, Li X and Wang R 2001 Records of Toba eruptions in the South China Sea. Chemical characteristics of the glass shards from ODP 1143A; Sci. China, Series D: Earth Sciences 44 871-878.

Liu Z, Colin C and Trentesaux A 2006 Major element geochemistry of glass shards and minerals of the Youngest Toba Tephra in the southwestern South China Sea; J. Asian Earth Sci. 27 99-107.

Mark D F, Barfod D, Stuart F M and Imlach J 2009 The ARGUS multicollector noble gas mass spectrometer: Performance for ${ }^{40} \mathrm{Ar} /{ }^{39} \mathrm{Ar}$ geochronology; Geochem. Geophys., Geosyst. 10 Q0AA02, 9 pp, doi: 10.1029/ 2009GC002643 [published online].

Martinez-Navarro B, Belmaker M and Bar-Yosef O 2009 The large carnivores from 'Ubeidiya (Early Pleistocene, Israel): Biochronological and biogeographical implications; J. Hum. Evol. 51 514-524.

Mishra S 2007 The Indian Lower Palaeolithic; Bull. Deccan College Post-Graduate Res. Inst. 66-67 47-94.

Mishra S 2008 The Lower Palaeolithic: A review of recent findings; Man Environ. 33 14-29.

Mishra S and Rajaguru S N 1994 Comment on "Toba Ash on the Indian subcontinent and its implication for the correlation of Late Pleistocene alluvium"; Quat. Res. 41 396-397.

Mishra S and Rajaguru S N 1996 Comment on "New geochemical evidence for the Youngest Toba Tuff in India"; Quat. Res. 46 340-341.

Mishra S, Venkatesan T R, Rajaguru S N and Somayajulu B L K 1995 Earliest Acheulian industry from Peninsular India; Curr. Anthropol. 36 847-851.

Mishra S, White M J, Beaumont P, Antoine P, Bridgland D R, Howard A J, Limondin-Lozouet N, McNabb J, Schreve D C, Wenban-Smith F F and Westaway R 2007 Fluvial deposits as an archive of early human activity; Quat. Sci. Rev. 26 2996-3016.

Mishra S, Gaillard C, Deo S, Singh M, Abbas R and Agrawal N 2009 Large Flake Acheulian in India: Implications for understanding lower Pleistocene human dispersals; Quat. Int. 223-224 271-272.

Misra V N, Rajaguru S N, Raghavan H and Gaillard C 1982 Acheulian occupation and evolving landscape around Didwana in the Thar Desert; Man Environ. 6 72-86.

Morgan L E, Renne P R, Taylor R E and WoldeGabriel G 2009 Archaeological age constraints from extrusion ages of obsidian: Examples from the Middle Awash, Ethiopia; Quat. Geochronol. 4 193-203.

Naeser N D and Naeser C W 1984 Fission-track dating; In: Quaternary Dating Methods: Developments in Palaeontology and Stratigraphy (ed.) Mahaney W C (Amsterdam: Elsevier) 7 87-100.

Naeser C W, Izett G A and Obradovich J D 1980 Fissiontrack and $\mathrm{K}-\mathrm{Ar}$ ages of natural glasses; U.S. Geol. Surv. Bull. 1489 1-31.

Ninkovich D, Shackleton N J, Abdel-Monem A A, Obradovich J D and Izett G 1978 K-Ar age of the Late Pleistocene eruption of Toba, north Sumatra; Nature 276 $574-577$.

Nishimura S, Abe E, Yojoyama T, Wirasantosa S and Dharma A 1977 Danau Toba - the outline of Lake Toba, north Sumatra, Indonesia: Paleolimnology of Lake Biwa; Japan Pleistocene 5 313-332.

Paddayya K 2007 The Acheulean of peninsular India with special reference to the Hungsi and Baichbal valleys of the lower Deccan; In: The Evolution and History of Human Populations in South Asia: Inter-disciplinary Studies in Archaeology, Biological Anthropology, Linguistics and Genetics (eds) Petraglia M and Allchin B (Dordrecht, The Netherlands: Springer), pp. 97-119.

Paddayya K, Blackwell B A B, Jhaldiyal R, Petraglia M D, Fevrier S, Chaderton D A, Blickstein J I B and Skinner A R 2002 Recent findings on the Acheulian of the Hunsgi and Baichbal valleys, Karnataka, with special reference to the Isampur excavation and its dating; Curr. Sci. 83(5) 641-647.

Paine J H, Nomade S and Renne P R 2006 Quantification of ${ }^{39}$ Ar recoil ejection from GA1550 biotite during neutron irradiation as a function of grain dimensions; Geochim. Cosmochim. Acta $\mathbf{7 0}$ 1507-1517.

Pareek H S 1981 Petrochemistry and petrogenesis of the Malani igneous suite, India; Geol. Soc. Am. Bull. 92(II) 206-273.

Patranabis-Deb S, Schieber J and Basu A 2009 Almandine garnet phenocrysts in a $\sim 1$ Ga rhyolitic tuff from central India; Geol. Mag. 146 133-143.

Pattan J N, Prasad M S and Babu E V S S K 2010 Correlation of the Oldest Toba Tuff to sediments in the central Indian Ocean basin; J. Earth Syst. Sci. 119 531-539.

Petraglia M D and Allchin B 2007 Human evolution and culture change in the Indian subcontinent; In: The Evolution and History of Human Populations in South Asia: Interdisciplinary Studies in Archaeology, Biological Anthropology, Linguistics and Genetics (eds) Petraglia M D and Allchin B (Dordrecht, The Netherlands: Springer), pp. $1-20$.

Petraglia M D, Laporta P and Paddayya K 1999 Isampur, the first Acheulian quarry in India: Stone tool manufacture, biface morphology and behaviours; J. Anthropol. Res. 55 39-70.

Petraglia M, Korisettar R, Boivin N, Clarkson C, Ditchfield P, Jones S, Koshy J, Mirazón Lahr M, Oppenheimer C, Pyle D, Roberts R, Schwenninger J-L, Arnold L and White K 2007 Middle Paleolithic assemblages from the Indian sub-continent before and after the Toba super-eruption; Science 317 114-116. 
Pillans B 2004 Tektites as chronostratigraphic markers in Australian regolith; In: Regolith 2004, Co-operative Research Centre for Landscape, Environments and Mineral Exploration (CRC LEME) (ed.) Roach I C (Australia: Canberra) pp. 279-281.

Prasad M S, Gupta S M and Kodagali V N 2003 Two layers of Australasian impact ejecta in the Indian Ocean?; Meteorit. Planet. Sci. 38 1373-1381.

Renne P R, Swisher C C, Deino A L, Karner D B, Owens T L and DePaolo D J 1998 Intercalibration of standards, absolute ages and uncertainties in ${ }^{40} \mathrm{Ar} /{ }^{39} \mathrm{Ar}$ dating; Chem. Geol. 145 117-152.

Rose W I and Chesner C A 1987 Dispersal of ash in the great Toba eruption, 75 ka; Geology 15 913-917.

Rose W I and Chesner C A 1990 Worldwide dispersal of ash and gases from Earth's largest known eruption: Toba, Sumatra, 75 ka; Palaeogeogr. Palaeoclimatol. Palaeoecol. $89269-275$.

Sangode S, Mishra S, Naik S and Deo S 2007 Magnetostratigraphy of the Quaternary sediments associated with some Toba Tephra and Acheulian artefact bearing localities in Western and Central India; Gondwana Mag. 10 111-121.

Schneider D A, Kent D V and Mello G A 1992 A detailed chronology of the Australasian impact event, the Brunhes-Matuyama geomagnetic polarity reversal, and global climate change; Earth Planet. Sci. Lett. 111 395-405.

Shackleton N J, Berger A and Peltier W R 1990 An alternative astronomical calibration of the Lower Pleistocene timescale based on ODP Site 677; Trans. Roy. Soc. Edinburgh: Earth Sci. 81 251-261.

Shane P, Westgate J, Williams M and Korisettar R 1995 New geochemical evidence for the Youngest Toba Tuff in India; Quat. Res. 44 200-204.

Shane P, Self S, Blake S and Rampino M R 2004 First Toba supereruption revival: Comment; Geology online forum 32 e 54.

Sharma R S 2009 Cratons and Fold Belts of India (Dordrecht, The Netherlands: Springer) 304 p.

Sharon G 2007 Acheulian large flake industries: Technology, chronology, and significance; British Archaeol. Rep. Int. Ser. 1701 1-236.

Shete G 2006 Geoarchaeology of the Wardha Valley; Ph.D. Thesis, Deccan College Pune, India.

Singer B S and Pringle M S 1996 Age and duration of the Matuyama-Brunhes geomagnetic polarity reversal from ${ }^{40} \mathrm{Ar} /{ }^{39} \mathrm{Ar}$ incremental heating analysis of lavas; Earth Planet. Sci. Lett. 139 47-61.

Smit J, van Eijden A J M and Troelstra S R 1991 Analysis of the Australasian microtektite event, the Toba Lake event, and the Cretaceous/Paleogene boundary; Proceedings of the Ocean Drilling Program, Scientific Results $\mathbf{1 2 1}$ 489-503.

Steiger R H and Jäger E 1977 Convention on the use of decay constants in geo- and cosmochronology; Earth Planet. Sci. Lett. 36 359-363.

Straffin E C, Blum M D, Colls A and Stokes S 1999 Alluvial stratigraphy of the Loire and Arroux rivers; Quaternaire $10271-282$.

Sukheswala R N and Poldervaart A 1958 Deccan basalts of the Bombay area, India; Geol. Soc. Am. Bull. 69 1473-1494.

Tchernov E 1987 The age of the 'Ubeidiya Formation, an Early Pleistocene hominid site in the Jordan Valley, Israel; Israel J. Earth Sci. 36 3-30.

Tchernov E 1999 The earliest hominids in the southern Levant; In: Proceedings of the International Conference of Human Palaeontology, Orce, Spain, 1995. Museo de Prehistoria y Paleontologia, Orce, Spain, pp. 389-406.

Tiwari M P, Bhai H Y, Padhi P N and Bandopadhyay K P 1996 Geomorphology and geology of the Purna valley; In: Proceedings of 1996 Symposium on Integrated Approach to Management of Water and Soil of the Purna Basin with Special Reference to Salinity Characteristics, Nagpur, India, pp. 11-20.

Turner G and Cadogan P 1974 Possible effects of ${ }^{39}$ Ar recoil in ${ }^{40} \mathrm{Ar} /{ }^{39} \mathrm{Ar}$ dating; In: Proceedings of the 5th Lunar and Planetary Science Conference, pp. 1601-1615.

Walker G P L 1971 Grain-size characteristics of pyroclastic deposits; J. Geol. 79 696-714.

Walker M J C 2005 Quaternary Dating Methods (Chichester: Wiley) $286 \mathrm{p}$.

Westaway R 2004 Pliocene and Quaternary surface uplift revealed by sediments of the Loire-Allier river system, France; Quaternaire 15 103-115.

Westaway R, Bridgland D and Mishra S 2003 Rheological differences between Archaean and younger crust can determine rates of Quaternary vertical motions revealed by fluvial geomorphology; Terra Nova 15 287-298.

Westaway R, Bridgland D R, Sinha R and Demir T 2009 Fluvial sequences as evidence for landscape and climatic evolution in the Late Cenozoic: A synthesis of data from IGCP 518; Global Planet. Change 68 237-253.

Westgate J A, Shane P A R, Pearce N J G, Perkins W T, Korisettar R, Chesner C A, Williams M A J and Acharyya S K 1998 All Toba tephra occurrences across peninsular India belong to the 75,000 yr B.P. eruption; Quat. Res. 50 107-112.

Williams M A J and Royce K 1982 Quaternary geology of the Middle Son valley, North Central India: Implications for prehistoric archaeology; Palaeogeogr. Palaeoclimatol. Palaeoecol. 38 139-162. 